\title{
VIAJE A LA ETERNIDAD. EL GRUPO ESCULTÓRICO DEL PARQUE INFANTIL DE TRÁFICO (ELCHE, ALICANTE)
}

\author{
JOURNEY TO ETERNITY. THE SCULPTURAL GROUP OF THE \\ CHILDREN'S DRIVING PLAYGROUD (ELCHE, ALICANTE)
}

\author{
TERESA CHAPA BRUNET* \\ MARÍA BELÉN DEAMOS**
}

\begin{abstract}
Resumen: El hallazgo casual de varias esculturas ibéricas a norte de la ciudad de Elche provocó la realización de algunas campañas de excavación a partir de 1972. Entre las figuras destaca una esfinge en piedra caliza que lleva sobre sí una figura masculina y otra femenina. En este trabajo se realiza un estudio iconográfico de la pieza, así como una revisión de las características del hallazgo. El varón es interpretado como el alma de un difunto, mientras que la mujer se entiende como la representación de la diosa Tinnit, muy popular en esta zona en época ibérica. La esfinge actúa como transporte al más allá. Estos restos son analizados en su contexto regional y cronológico. Palabras clave: Península Ibérica; Elche; Edad del Hierro; Escultura ibérica; Escultura en piedra; Esfinge; Tinnit.
\end{abstract}

La singularidad del grupo escultórico recuperado en el Parque Infantil de Tráfico de Elche (Alicante) a principios de los años setenta del siglo XX, hace que sea una obra reiteradamente comentada en la bibliografía especializada (fig. 1). Sin embargo no ha sido objeto hasta el momento de un análisis técnico y estilístico pormenorizado como el que aquí nos proponemos abordar, en la línea del proyecto de investigación que desarrollamos sobre escultura ibérica ${ }^{1}$. Con este estudio nos adhe-

\footnotetext{
* Departamento de Prehistoria. Facultad de Geografía e Historia Universidad Complutense de Madrid. E-mail: tchapa@ghis.ucm.es.

** Departamento de Prehistoria y Arqueología. Facultad de Geografía e Historia. Universidad de Sevilla. E-mail: belendeamos@us.es

1. "Escultura ibérica: estudio iconográfico, tecnológico e historiográfico" (HUM2007/60074), financiado por el Ministerio de Ciencia e Innovación. El trabajo se adscribe también a los proyectos "Tinnit en Ibiza" (HUM 2007/63574) y "Religio Phoenicia Occidentalis”
}

Summary: Several archaeological campaigns starting in 1972 followed the accidental finding of some Iberian sculptures at the north of the town of Elche. Among them stands the figure of a Sphinx in limestone carrying a male and a female figure. In this paper an iconographic study is performed, as well as an overview of the characteristics of the finding. The man is interpreted as the soul of a deceased, and the women as a representation of the goddess Tinnit, very popular in this area during Iberian times. The sphinx acts as a suitable transport for the journey to the underworld. These remains are understood in their regional and chronological context.

Keywords: Iberian Peninsula; Elche; Iron Age; Iberian sculpture; Stone sculpture; Sphinx; Tinnit.

rimos afectuosamente al homenaje que el Departamento de Prehistoria y Arqueología de la Universidad de Sevilla dedica al profesor Manuel Bendala y reconocemos su relevante aportación científica en este campo temático.

\section{CARACTERÍSTICAS Y CONTEXTO DEL HALLAZGO}

Los primeros hallazgos escultóricos aparecieron de forma casual, al abrir una zanja para instalar una conducción de agua potable al este del Parque Infantil de

(HAR2011-272579), aprobados y sostenidos económicamente por el mismo organismo. Queremos expresar nuestro sincero agradecimiento a D. Rafael Ramos Fernández, director del Museo Arqueológico y de Historia de Elche, por facilitarnos el estudio de la pieza. 

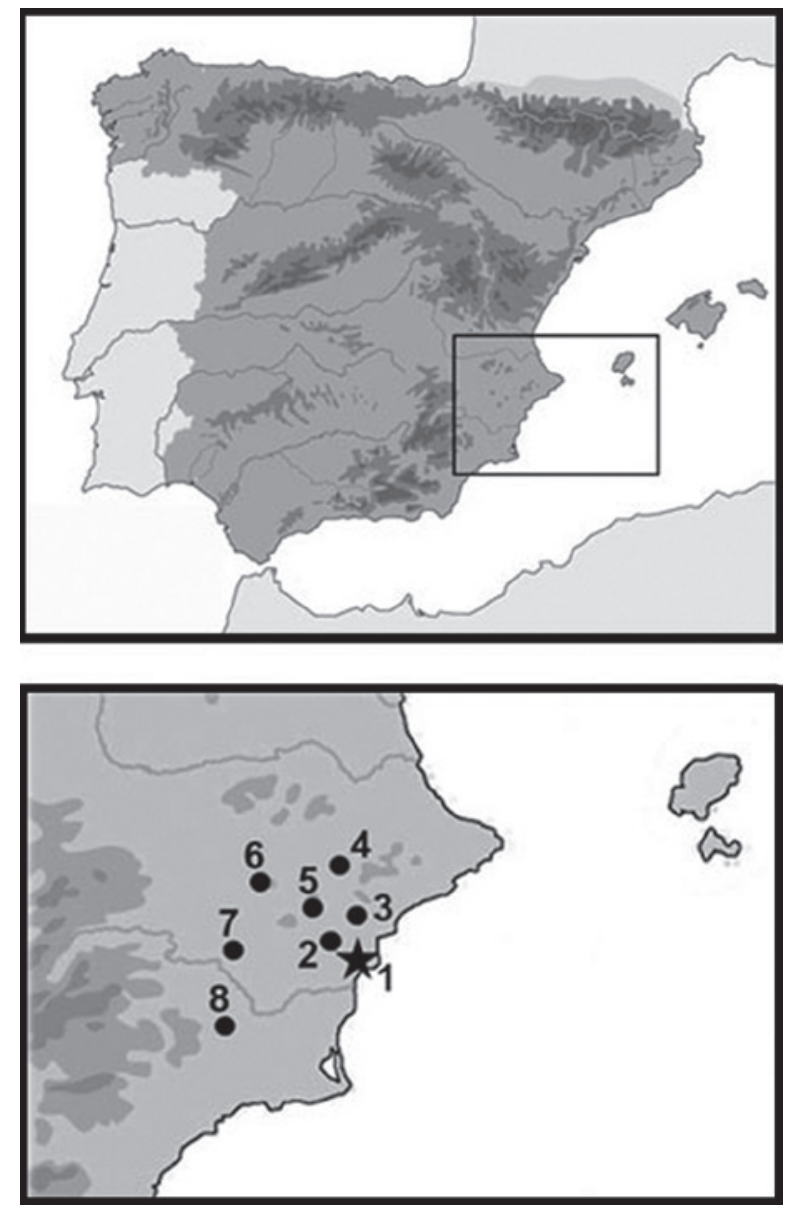

Figura 1. Localización de los yacimientos citados en el texto. 1. Yacimientos de Elche; 2. Monforte del Cid; 3. Agost; 4. Corral de Saus; 5. El Monastil; 6. El Salobral; 7. Bogarra; 8. Nerpio.

Tráfico. Consistieron en la parte delantera de la esfinge, la mitad delantera de un toro que en un principio fue clasificado como pájaro, y el extremo de una pata de caballo en altorrelieve (fig. 2). Estos descubrimientos provocaron el desarrollo de excavaciones arqueológicas a partir de 1972 en las que se recuperaron otros muchos restos escultóricos, arquitectónicos y cerámicos, entre los que hay que reseñar la parte posterior de la esfinge, cuyo cuerpo pudo ser así completado, y el torso de un guerrero con su espalda vaciada (Ramos Folqués y Ramos Fernández 1976: 684; Ramos Molina 2000: 45-47).

A pesar de que el entorno queda todavía en un área ajardinada, son muchas las alteraciones que ha sufrido el terreno hasta la actualidad. Los restos ibéricos, situados a una cota de $-1,90 \mathrm{~m}$, fueron afectados por una edificación romana con infraestructuras subterráneas
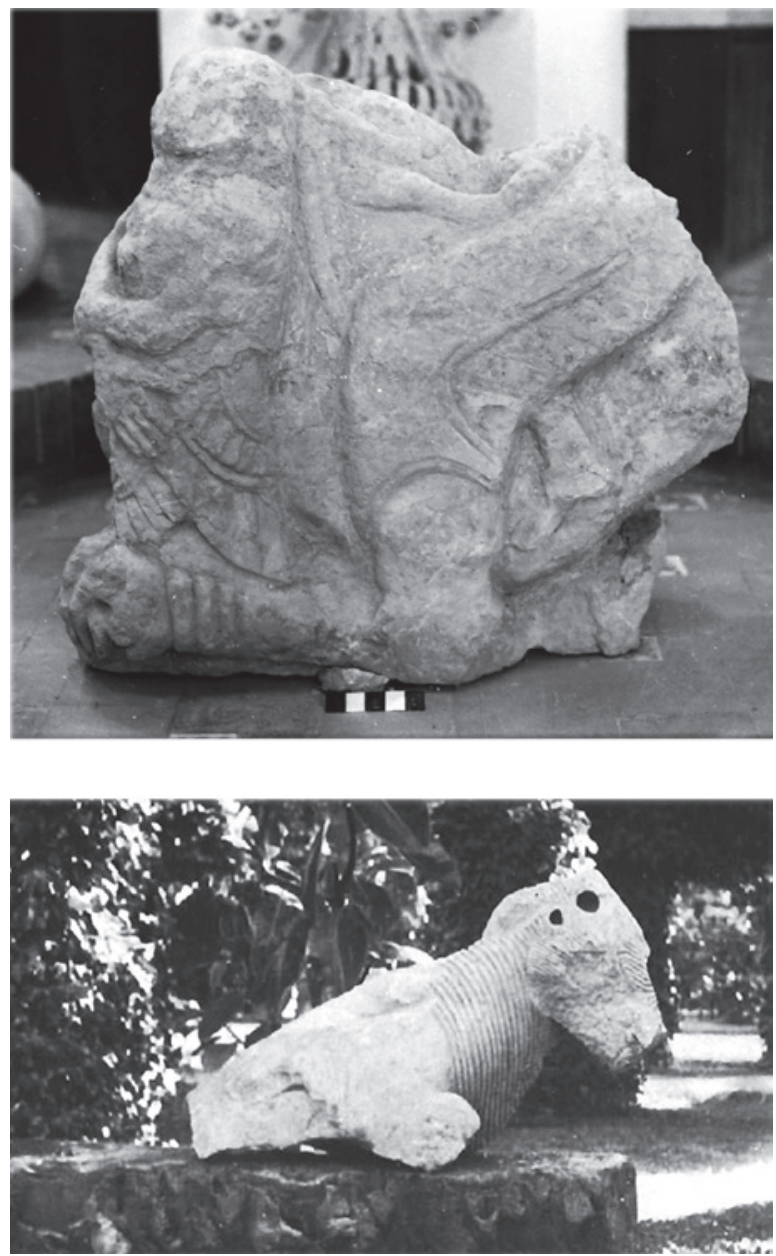

Figura 2. Primeros hallazgos escultóricos en el Parque Infantil de Tráfico: partes delanteras de la esfinge y el toro (a partir de Ramos Folqués y Ramos Fernández 1976).

de acometida y calentamiento de agua (Ramos Fernández 1987: 681). Posteriormente, la zona se dedicó al cultivo, dividiéndose en huertos servidos por acequias que perduraron hasta época reciente. En 1946 el Ayuntamiento transformó las huertas en el "Parque de Elche"2, en cuyo recinto se construiría después el "Parque Infantil de Tráfico". Este se sitúa inmediatamente al norte de la vía férrea, hoy soterrada. En su zona occidental se abre el profundo cauce del Vinalopó, mientras que al oriente de la zona excavada discurre un camino que desde Elche se dirige a las sierras situadas al norte de la población. A poco más de $600 \mathrm{~m}$, también hacia el este, pasa el "Camino de Castilla", ruta histórica que

2. Información consultada en http://www.turismedelx.com/es/ palmeras/1/, (30_08_2011) 

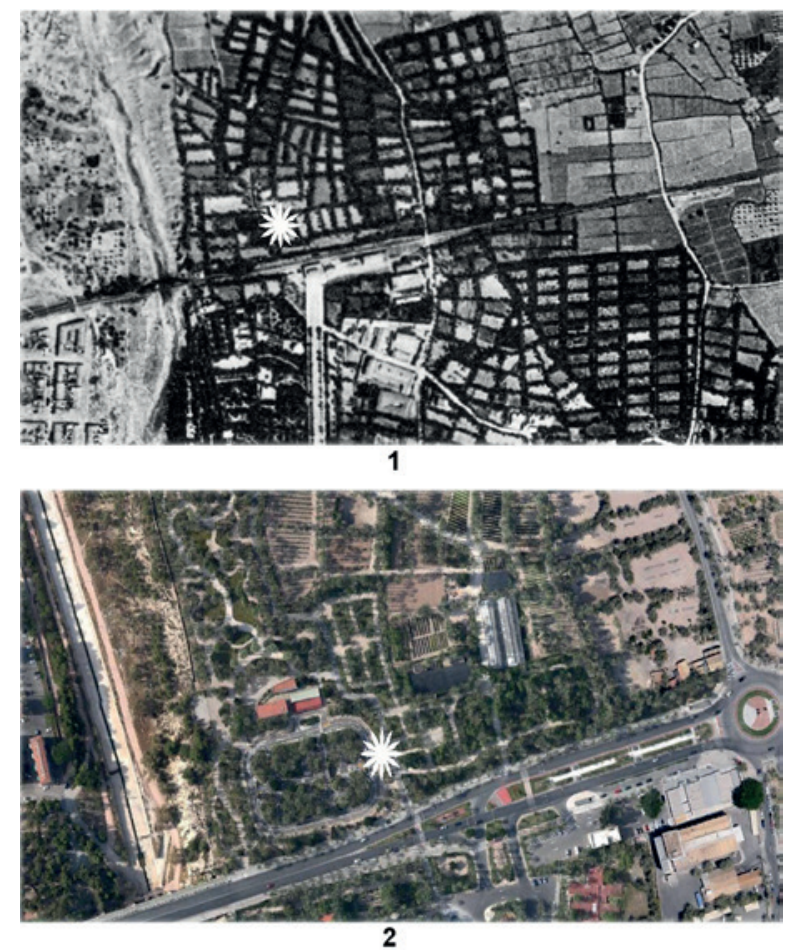

Figura 3. Localización del hallazgo en la foto aérea del "vuelo americano" de 1956 y en la imagen de satélite de Google Earth.

enlazaba la costa con la Meseta, a lo largo de la cual hay una notable concentración de monumentos escultóricos ibéricos (fig. 3).

Durante las excavaciones arqueológicas se localizó un alineamiento ovalado, formado en su mayor parte por piezas escultóricas fragmentadas. Su eje mayor discurría en dirección norte-sur, y solo su lado oeste se había conservado bien, ya que el oriental había sido muy afectado por las construcciones romanas. Las piedras bordeaban un estrato de arcilla de hasta $60 \mathrm{~cm}$ de grosor (fig. 4). En la parte central de esta plataforma arcillosa se situaba una piedra de forma subcircular, recortada y aplanada artificialmente (fig. 5). En los márgenes del lado occidental, y en un estrato de $16 \mathrm{~cm}$ de grosor, se recuperaron unos 5.000 fragmentos cerámicos infrapuestos y superpuestos a los restos escultóricos. Además, al exterior de esta zona se reconoció la existencia de un curso de agua en cuyo lecho también se recogieron numerosos restos "rotos intencionalmente", entre los que destacaban fragmentos de ánforas ibéricas de asa acanalada (Ramos Fernández 1989: 508). Los excavadores consideraron que las piezas escultóricas, una vez desmontadas del monumento al que hubieran pertenecido, se emplearon para delimitar un

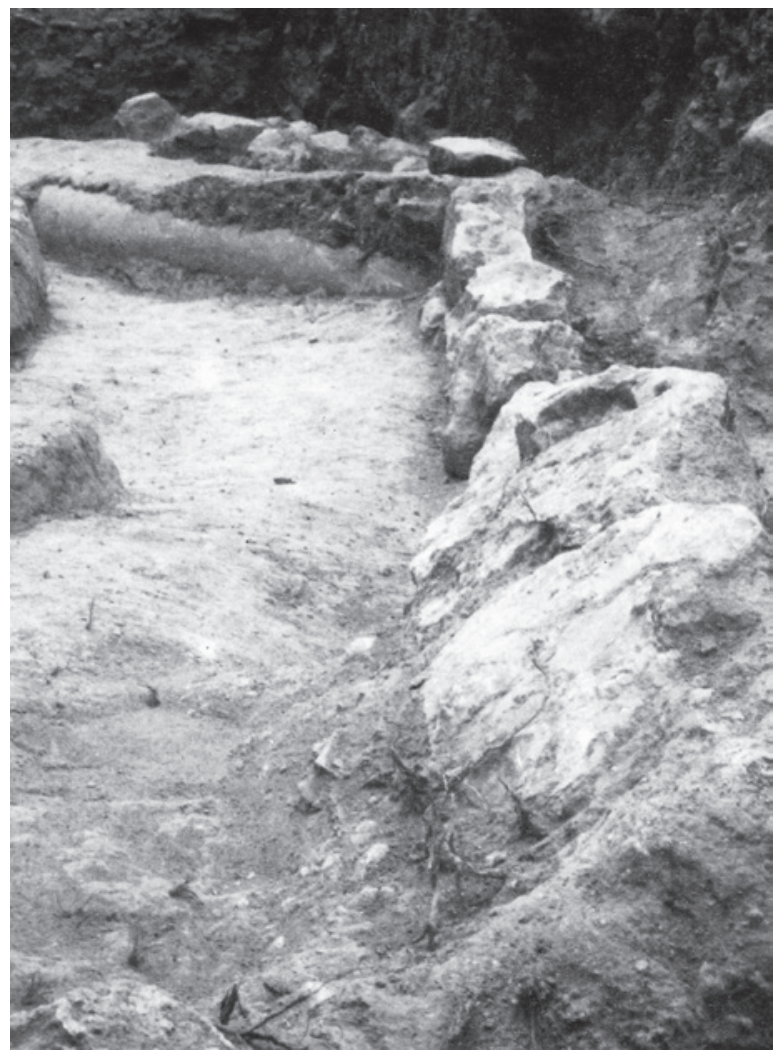

Figura 4. Hallazgo de las esculturas en el recinto del "témenos" (según Ramos Fernández y Ramos Molina 1992).

lugar de culto preexistente, que siguió siendo utilizado en épocas posteriores (fig. 6).

El monumento al que se suele asociar la esfinge, tal como queda expuesta en las salas del Museo Municipal de Elche, está compuesto por sillares cuyos restos formaban parte de los muros de la villa romana. $\mathrm{Su}$ asignación a época ibérica se basa en la existencia de un rebaje cuadrado de $3,30 \mathrm{~m}$ de lado y una profundidad de $40 \mathrm{~cm}$, situado en la parte norte de la plataforma de arcilla, junto a un área quemada. El tamaño y morfología de las piedras labradas han llevado a reconstruir esta edificación como una torre de remate piramidal sobre una base de sillares ciclópeos de 1,90 m de longitud. Su altura total propuesta sería de $3,30 \mathrm{~m}$ y la longitud del segundo cuerpo de $1,22 \mathrm{~m}$, prácticamente coincidente con la longitud de la esfinge, que se ha colocado adosada a uno de sus lados ${ }^{3}$ (fig. 7).

3. Las dimensiones no coinciden con las del rebaje en el que supuestamente encajaba la base del monumento. En su exposición actual, la torre se presenta acortada en altura por los condicionantes de la sala.

ISSN: 1133-4525 ISSN-e: 2255-3924 


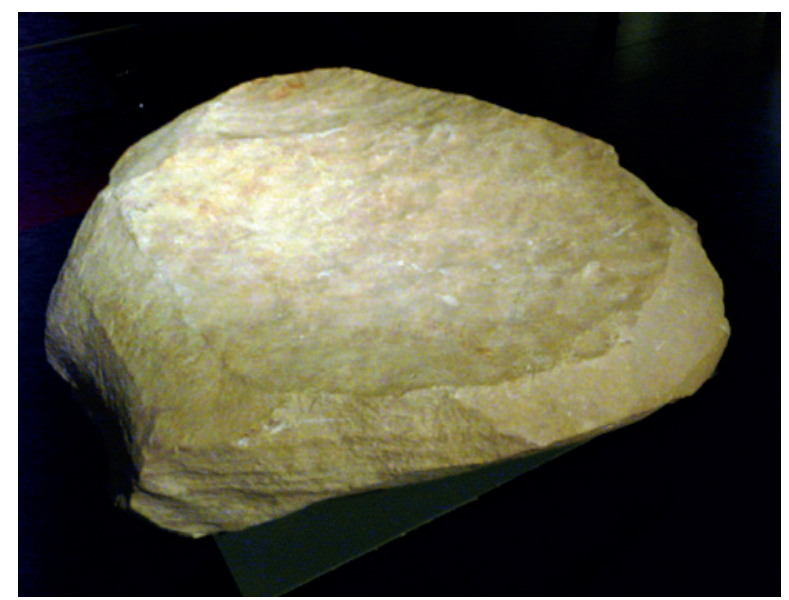

Figura 5. Piedra central del "témenos" (Foto T. Chapa).

Las limitaciones de este trabajo no permiten abordar el estudio integrado de la esfinge y el monumento al que supuestamente pertenecería, por lo que vamos a limitarnos a realizar un análisis técnico e iconográfico de la escultura que esperamos arroje alguna luz sobre esta sorprendente pieza de la estatuaria ibérica.

\section{DESCRIPCIÓN DE LA PIEZA}

La escultura representa a una esfinge posada en tierra que soporta a dos personajes humanos: una figura femenina de pie sobre sus patas delanteras que se reclina sobre el cuello y pecho del animal y un personaje cabalgando sobre su lomo. Falta la cabeza, el extremo del ala y la garra delantera derecha de la esfinge, así como la parte superior del tronco y cabeza del personaje masculino. La figura femenina, aunque prácticamente completa, tiene la cabeza tan deteriorada que apenas se aprecian detalles del rostro y cabello. Para facilitar su comprensión, en la exposición museográfica se han reconstruido las partes perdidas (figs. 7 y 8).

La obra es un altorrelieve concebido casi como bulto redondo, al limitar la zona no tallada del bloque a la parte externa del lado derecho. La perspectiva visual preferente de la pieza es, por tanto, su lado izquierdo, si bien también puede ampliarse al frente y parte trasera. El lado derecho está muy erosionado y presenta huellas de roce en sentido vertical sobre el costado de la esfinge, pero su acabado no es el que se esperaría en una pieza pensada para ser adosada a un sillar. En cualquier caso, parece claro que esta parte derecha no iba vista. La piedra en la que se ha realizado es una caliza procede de las cercanas canteras de El Ferriol, cuya explotación fue común en época ibérica (Gagnaison et al. 2007: 76).

La longitud de la escultura es de $120 \mathrm{~cm}$, su grosor máximo de $32 \mathrm{~cm}$ y la altura conservada de $64 \mathrm{~cm}$. Dado que contamos con la longitud original de la pieza, esto nos permite hacer una serie de propuestas sobre su posible modulación. La división de esta longitud en tres segmentos de $40 \mathrm{~cm}$ nos marca áreas clave de la

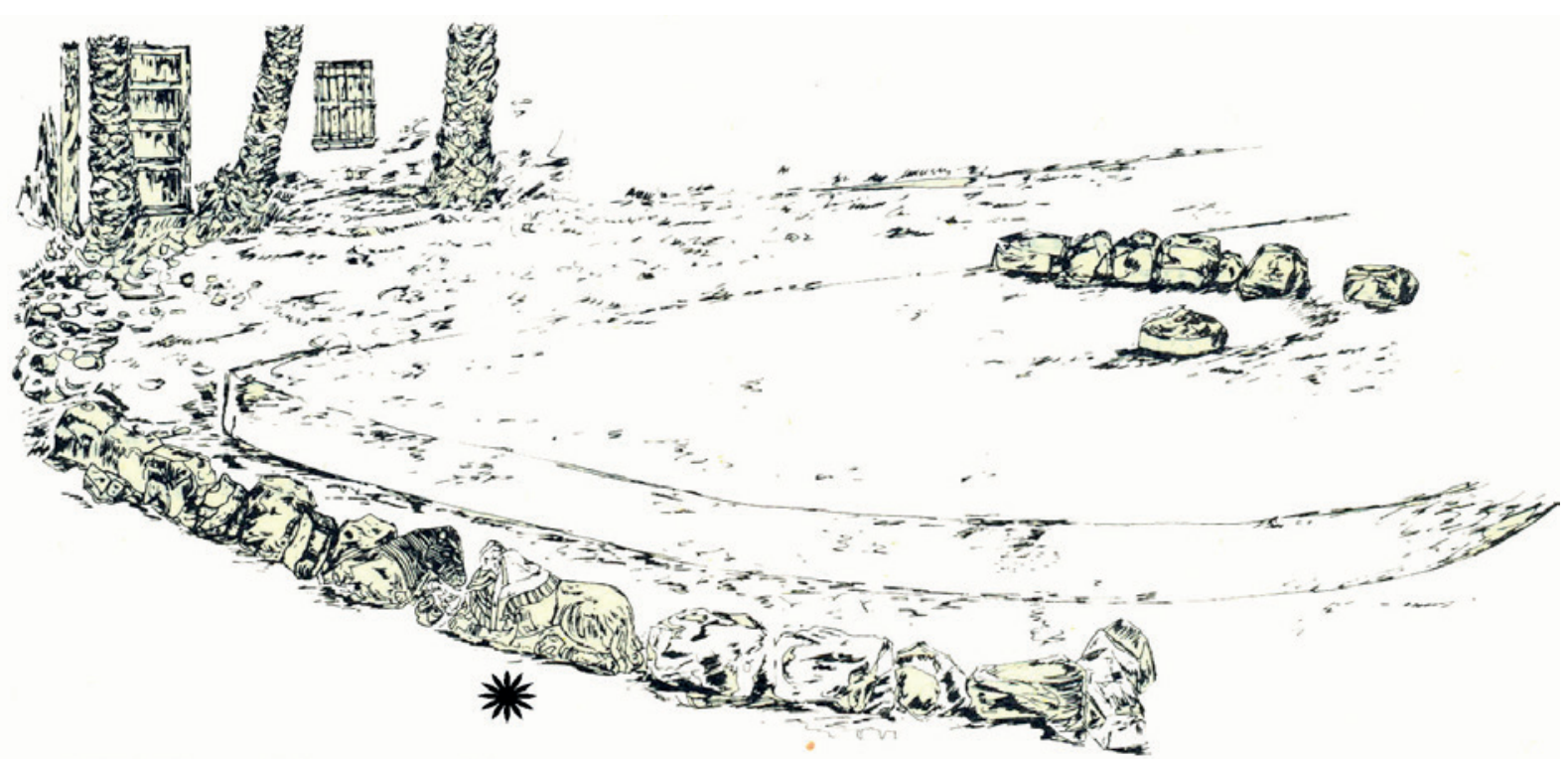

Figura 6. Reconstrucción del "témenos" indicando el lugar ocupado por la esfinge (según Ramos Fernández y Ramos Molina 1992). 


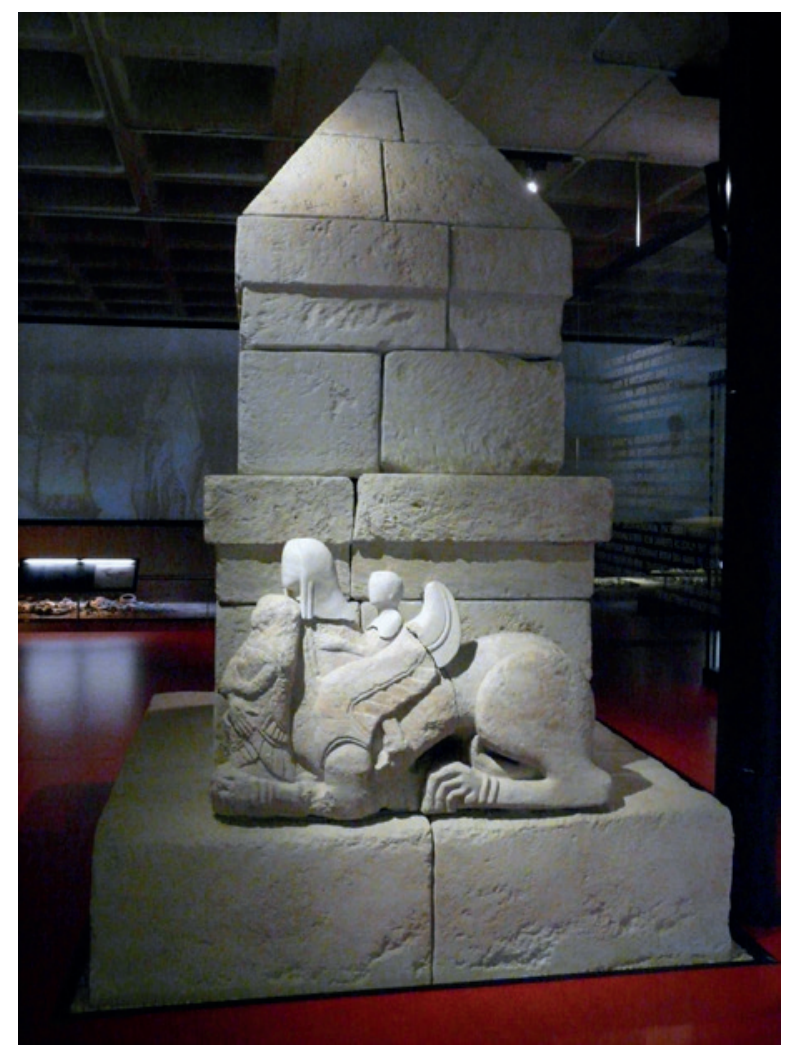

Figura 7. Esfinge adosada al monumento de sillería con remate piramidal (Foto T. Chapa).

distribución interna de la representación, encajando la primera de las líneas con el centro del brazo delantero de la esfinge y posiblemente la parte trasera de su cabeza, mientras que la segunda nos indica el arranque de la garra posterior, el límite delantero de su cintura escapular y el punto de inflexión del final del lomo. Basándonos en cómo se aplicó la modulación a las dimensiones del "torito" de Porcuna (Chapa y Vallejo e.p.), en el que la altura se reduce a dos tercios de la longitud, podemos aventurar también una posible altura máxima para esta pieza de $80 \mathrm{~cm}$, que coincide prácticamente con la restitución de la cabeza que hoy se presenta en el Museo de Elche (fig. 9). Con estas dimensiones máximas, la escultura habría sido tallada sobre un bloque calizo que tendría en torno a $130 \times 40 \times 90 \mathrm{~cm}$, lo que equivale a un peso próximo a $600 \mathrm{~kg}$.

La figura de la esfinge es la base de la representación. Su cuerpo, largo y poderoso, causa hoy menos impacto a los espectadores debido a la falta de la cabeza, de cuyo peinado descienden por el cuello dos tirabuzones unidos que alcanzan la curva delantera del ala. Esta surge sobre el brazo a partir de una doble incisión también curva, y se compone de dos cuerpos. El delantero es liso, mientras que el posterior, separado por otra doble incisión, indica unas plumas horizontales, anchas y cortas, marcadas mediante relieves escalonados. La parte alta del ala superaba el brazo y el hombro, extendiéndose sobre la zona central del lomo, donde su curvatura indica un posible arco. El final del ala no sería totalmente exento, sino que se adosaría a la cabeza del personaje central, facilitando así la talla y asegurando la estabilidad de este apéndice. La reproducción actual en el Museo de Elche la sitúa como elemento independiente, pero su curvatura rompe con la que muestra el ala original. El codo se encuentra parcialmente fracturado, aunque permite apreciar su alargamiento exagerado, como sucederá con la zona de la rodilla. El antebrazo da paso a la garra mediante tres resaltes verticales bien marcados que han sido denominados "pulseras" (Ramos Fernández 1988: 367), aunque pudieran ser una manera de marcar la transición entre estas partes anatómicas. La garra tiene dedos gruesos, angulosos y apuntados, y se curva hacia el lado derecho para formar el frontal inferior de la representación, cerrando la base de la figura femenina que sostiene.
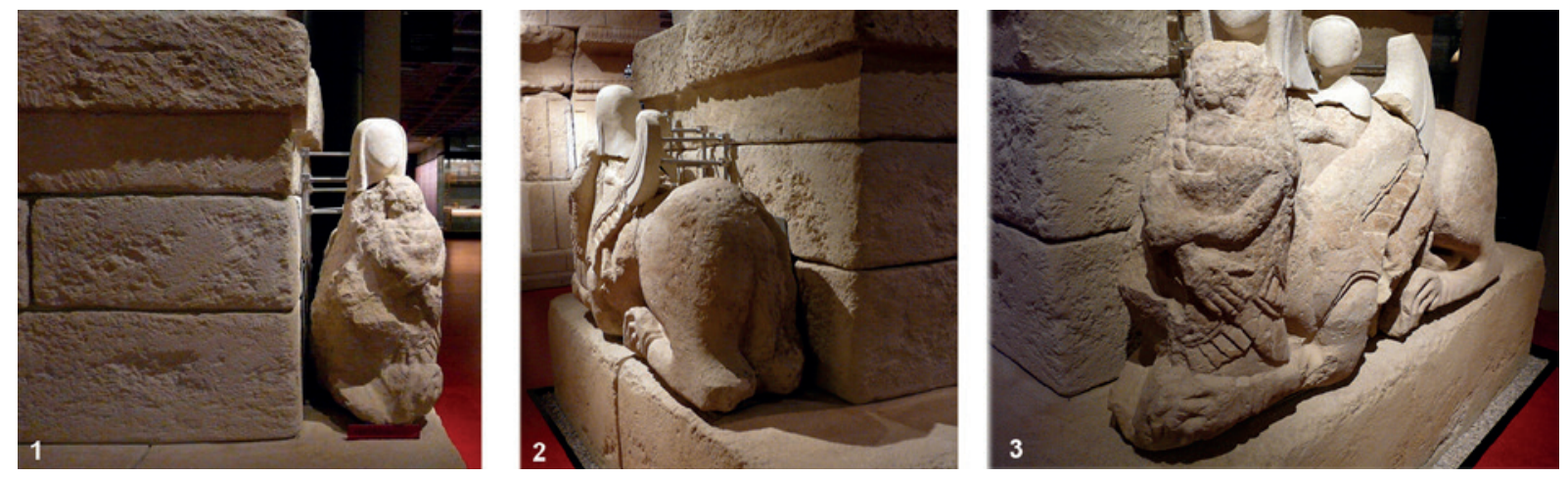

Figura 8. Vistas delantera, posterior y perspectiva delantera izquierda de la esfinge (Fotos MAHE).

ISSN: 1133-4525 ISSN-e: 2255-3924 

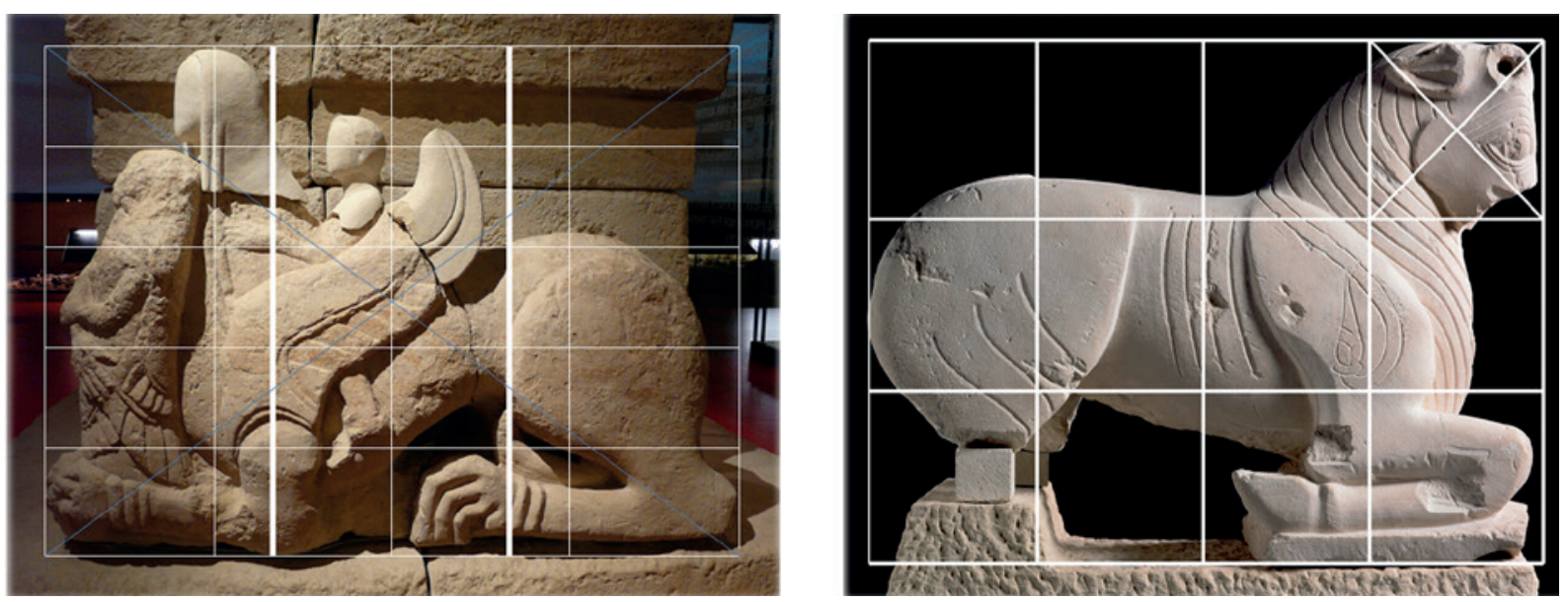

Figura 9. Encuadres proporcionales de la esfinge de Elche y el toro de Porcuna (Fotos T. Chapa).

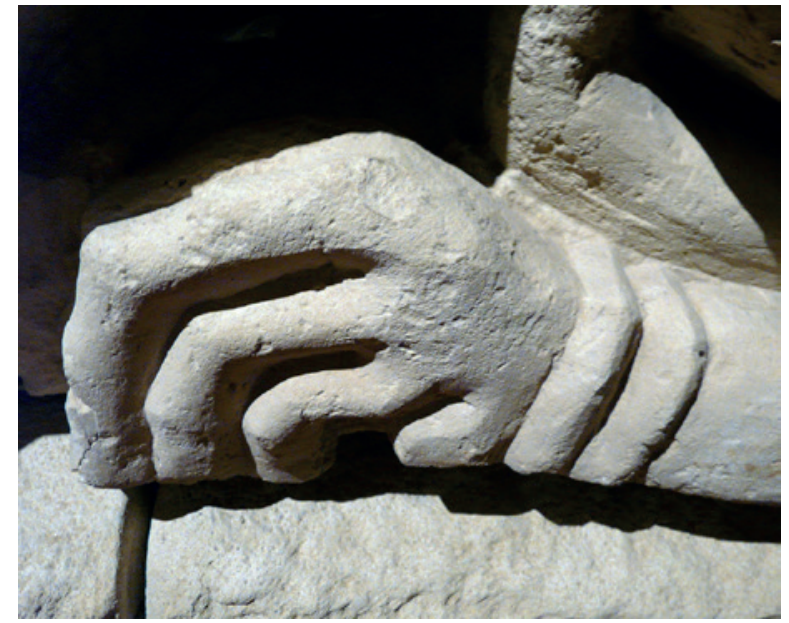

Figura 10. Garra trasera derecha de la esfinge (Foto T. Chapa).

El resto del cuerpo de la esfinge corresponde al de un felino, cuyo vientre se adelgaza y eleva notoriamente hasta entrar en contacto con los cuartos traseros. La parte superior del muslo izquierdo queda delineado mediante una semicircunferencia, estrechándose en su parte inferior para dar paso a la rodilla y a la pata doblada bajo el cuerpo. Entre el muslo y la muñeca se representa el extremo apuntado de la cola, que se curva hacia arriba y entra en contacto con la ingle. En la zona trasera se ha representado el inicio de esta cola, aunque la erosión impide definir con detalle sus características. Es ancha y ligeramente aplanada, y a pesar de que se representa su extremo por el lado izquierdo, en la zona trasera parece que termina con un reborde redondeado que indicaría su introducción entre las dos patas, aunque el resalte que adquiere en esta zona es excesivo para dar esta impresión. La garra trasera izquierda presenta de nuevo los rebordes o "pulseras" y sus dedos son angulosos, más próximos a un modelo humano que animal (fig. 10).

Sobre el anca del animal se aprecian incisiones circulares muy finas con una compartimentación interna geométrica (fig. 11). Son tres, situándose en una zona central una de ellas y las otras dos a sus lados en posición más alta. Su disposición es irregular, situándose las superiores a distinta altura y la central ligeramente desplazada hacia la izquierda y la parte inferior respecto al centro del anca. Las primeras han sido cubiertas por una costra o pátina fina que afecta a buena parte de la pieza, y de ellas sólo se puede apreciar parte del círculo exterior y alguna línea de su compartimentación interna. La central se conserva mejor y permite apreciar que los dos segmentos de círculo que la componen se realizaron con compás, cuya punta ha dejado una clara marca en la zona central de apoyo. Las líneas que se asocian a la parte interior de los cuadrantes y a una de sus zonas abiertas se han grabado a mano y son mucho más irregulares. Tres orificios paralelos, pequeños y superficiales, se sitúan algo más arriba del punto central. El diámetro de este círculo incompleto es de 7,2 cm.

Como se ha indicado, la esfinge es el elemento-soporte de dos figuras humanas. La femenina, situada de pie sobre las patas delanteras del animal, está prácticamente completa, aunque se encuentra muy erosionada. Se ha representado por sus lados frontal e izquierdo y su volumen se ciñe a esta parte del bloque general, que se ensancha en esta zona. Esto indica que su perspectiva no debía ser totalmente frontal, sino que los espectadores debían observar esta parte de la pieza desde su ángulo delantero izquierdo. Esto induce a una posición 

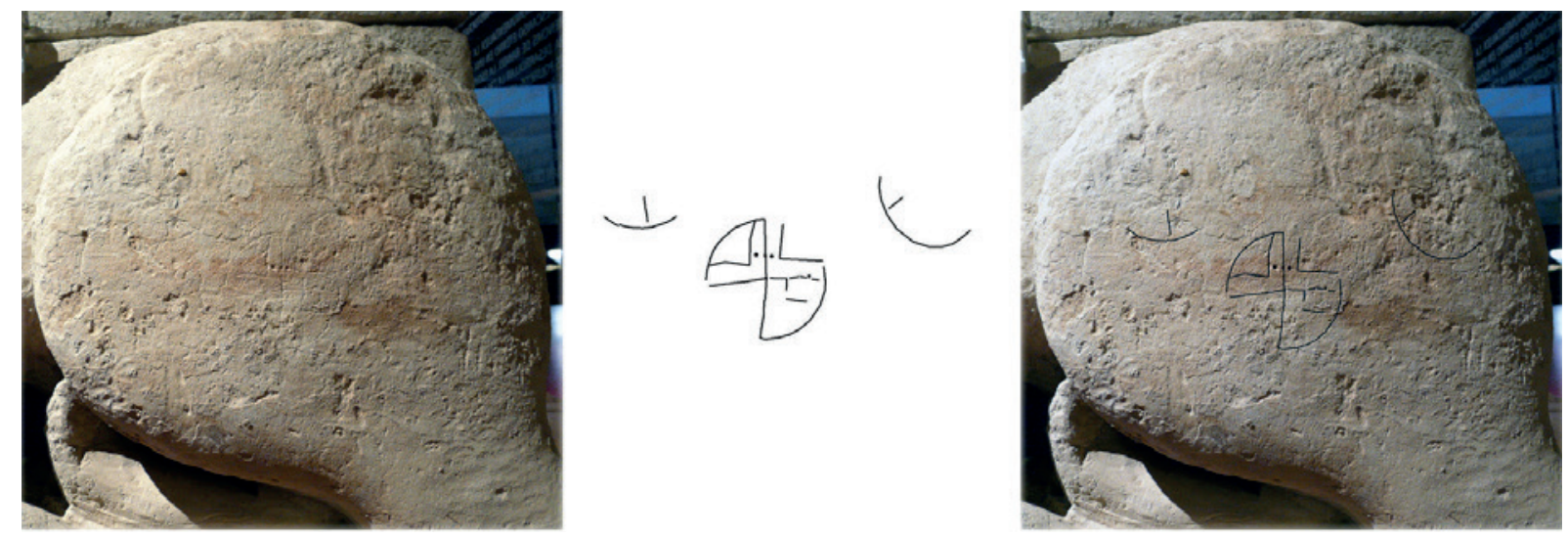

Figura 11. Incisiones localizadas en el muslo izquierdo de la esfinge (Fotos T. Chapa).

forzada del hombro y brazo derecho, que deben mostrarse sin respetar una perspectiva correcta de perfil, así como el hecho de que sea en el lateral izquierdo, y no en el centro, donde se cruzan las alas que cubren la túnica (fig. 12).

La figura, cuya altura máxima es de $52 \mathrm{~cm}$, inclina ligeramente su cabeza hacia la derecha, marcando claramente el lateral del rostro por este lado con un corte rectilíneo que la separa de algún elemento no conservado que se prolonga por su costado derecho. Sus rasgos faciales están muy perdidos, pero se advierten ligeros indicios de los ojos, una nariz longitudinal, la boca y la barbilla. La parte superior de la cabeza está dividida por un profundo surco, quizás fruto de la erosión o de un peinado original. Sin espacio para el cuello, el cuerpo cilíndrico surge directamente de la barbilla. Los brazos están desnudos a partir de los hombros y son largos y desproporcionados. El izquierdo está doblado sobre el vientre y sujeta con la mano el brazo derecho, atrayéndolo hacia sí, de forma que la mano de este lado, de grandes dimensiones, queda extendida a la altura de la rodilla izquierda. La talla adquiere en este caso un gran detalle, señalándose con cuidado los dedos, los nudillos y las uñas.

La vestimenta que porta es compleja, advirtiéndose un velo o manto corto y una túnica que cubren parcialmente dos alas con otras tantas capas de plumas, replegadas sobre el lateral izquierdo con la ayuda de la mano derecha. Las plumas son más anchas en la banda inferior (hasta $3 \mathrm{~cm}$ ), que en la superior (c. $2 \mathrm{~cm}$ ). Se puede considerar, y así lo han reconocido varios autores, como una divinidad alada (Ramos Fernández 1984-1985: 65; Marín Ceballos 1987: 66; Prados 20022003: 216; López Pardo 2006: 131). En su escote o pechera se ha representado en relieve una flor trilobulada
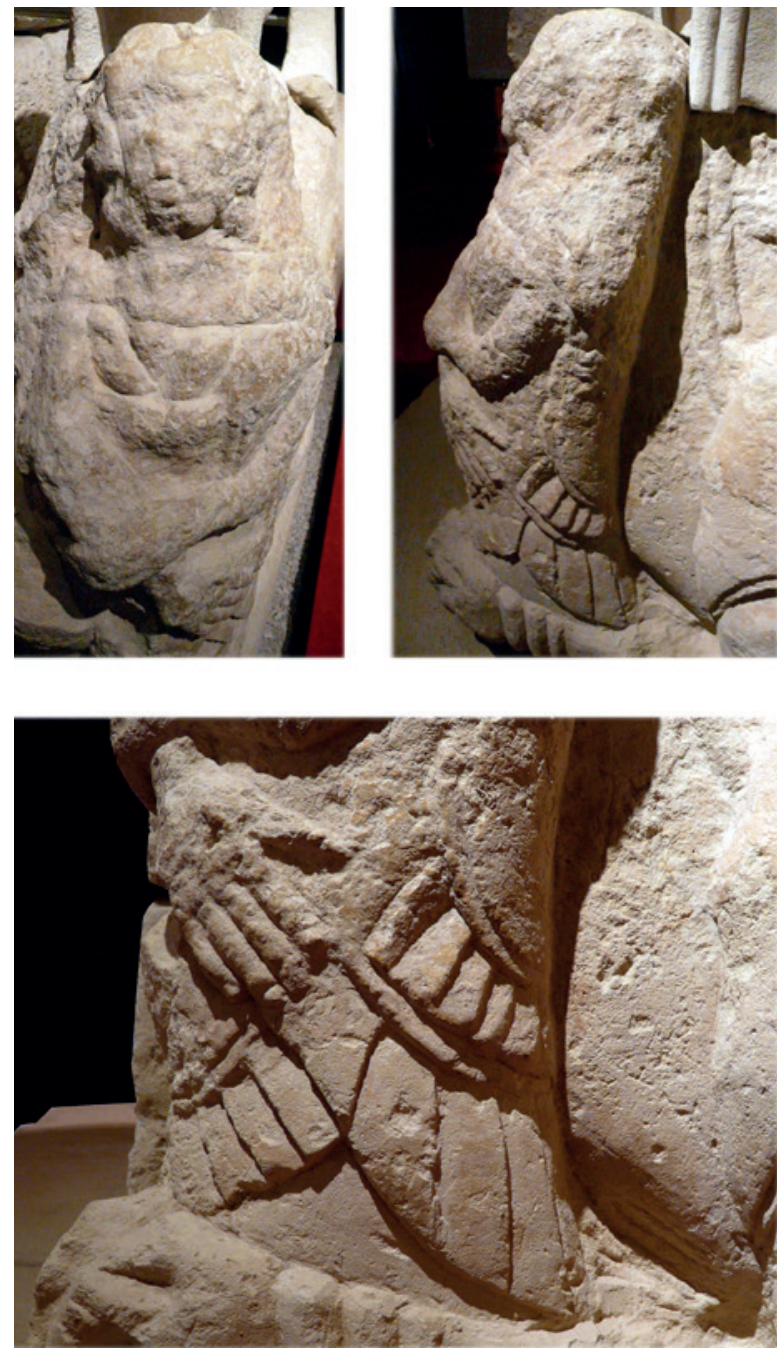

Figura 12. Detalles de la figura femenina y de su vestido de alas (Fotos T. Chapa). 

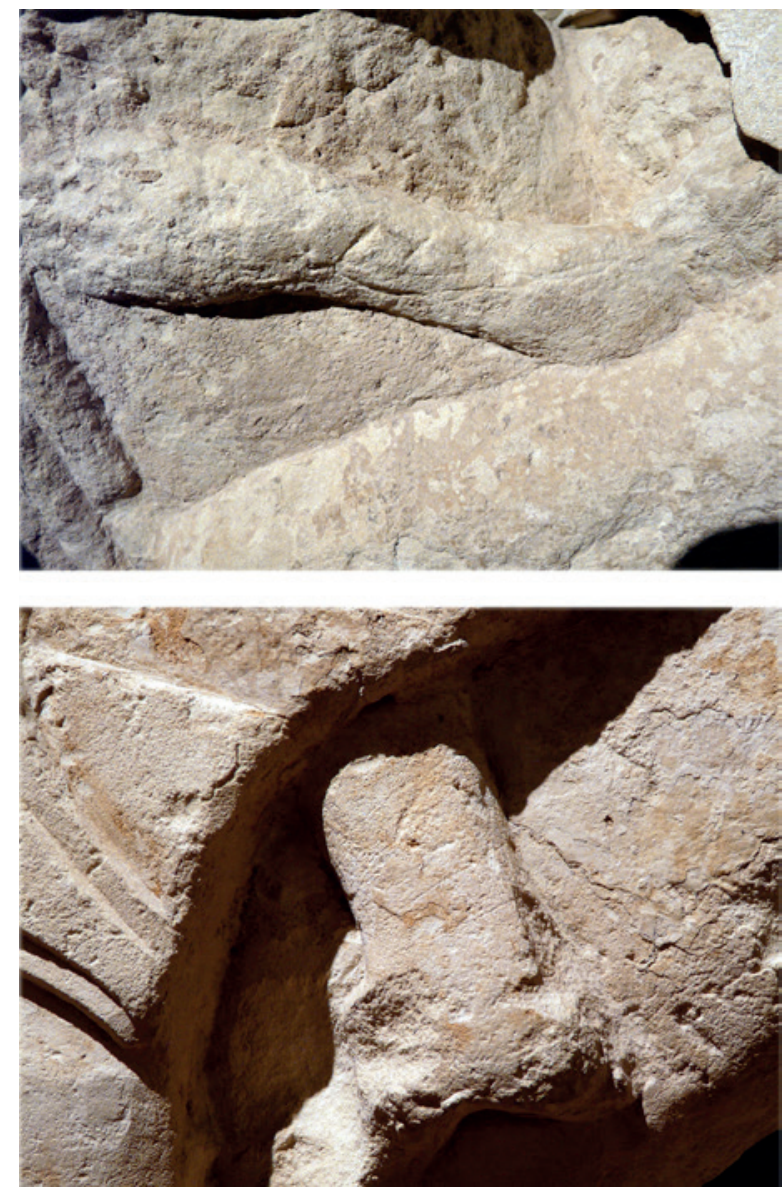

Figura 13. Detalles del brazo y pie del personaje montado sobre la esfinge (Fotos T. Chapa).

que adquiere especial relevancia por su tamaño proporcional y su alta visibilidad. La figura se apoya directamente sobre las patas delanteras de la esfinge y no se indican los pies. Por otro lado, su parte posterior es lisa y ligeramente curva, resaltándose bien respecto al cuello y cuerpo de la esfinge. Se trata, por tanto, de la representación de una efigie o estatua.

En cuanto a la figura central, es la más sencilla y parece representar a un varón que viaja sobre el lomo de la esfinge (fig. 13). Su pequeño tamaño indicaría quizás que se trata del alma de un difunto en su traslado al más allá. El cuerpo es desproporcionado, con un brazo izquierdo muy fino que alcanza a tocar con el extremo de sus dedos los tirabuzones de la esfinge, aferrándose a su cuello. Un ligero resalte sobre su codo parece indicar que llevaba túnica de manga corta. El extremo inferior de la pierna y el pie del mismo lado, de tamaño algo exagerado, surgen bajo el ala del animal, apoyándose oblicuamente sobre su cuerpo. El arco que forma la planta del pie es muy marcado y su extremo se afina notablemente en la zona de los dedos. La falta de la cabeza impide de nuevo aportar detalles que hubieran sido de gran interés para la valoración tecno-estilística de la pieza, pero lo más probable, como se ha dicho antes, es que formara un mismo cuerpo con el extremo del ala de la esfinge.

Además de la túnica, el personaje muestra sobre su tobillo cuatro incisiones paralelas muy finas situadas a distancia entre 0,8 y $1,4 \mathrm{~cm}$, que parecen limitar la parte superior de un calzado o bota. Estas marcas pudieron estar relacionadas con la definición de ciertos elementos diseñados mediante la aplicación de pinturas de colores o tonalidades diferentes. En el brazo de este personaje se realizaron igualmente una serie de surcos irregulares que van de la muñeca al codo. El inicio, junto a la muñeca, forma una línea quebrada de cuyos extremos surgen dos paralelas que se cruzan sobre el brazo. No puede reconocerse un motivo concreto, aunque de nuevo pudiera marcar elementos relacionados con la decoración, ya que el antebrazo no iría cubierto por la túnica.

\section{ESTUDIO ICONOGRÁFICO}

\section{La esfinge y su jinete}

La figura del Parque Infantil de Tráfico presenta diversos rasgos individualizadores respecto a otras esfinges ibéricas y seguramente el más importante es su asociación directa con figuras humanas. Lo primero que podría resaltarse es que a su condición de ser monstruoso se añade lo exagerado de su tamaño. Aunque las dimensiones del bloque obligan a representar a una esfinge cuyo cuerpo tiene en torno a un metro de largo, la proporción que adquiere respecto al varón que monta sobre su espalda nos indica la diferencia relativa entre ambos, que supera en mucho la que existiría entre un jinete y su caballo. Sus alas son así lo suficientemente anchas para sujetar al personaje en este vuelo protector hacia los infiernos (Olmos 2011: 122). Sin embargo, hay que tener presente otra posibilidad, y es que no estemos ante una representación del cuerpo real de un difunto, sino de su alma, que habitualmente se muestra como una figura de dimensiones reducidas.

Por ello, en varias ocasiones se ha relacionado la iconografía de la esfinge de Elche con la del Pilar de las Arpías de Xanthos (Chapa 1986: 378), un friso de mármol en relieve de poco más de un metro de altura, situado sobre un pilar de $5 \mathrm{~m}$ (fig. 14). La denominación 


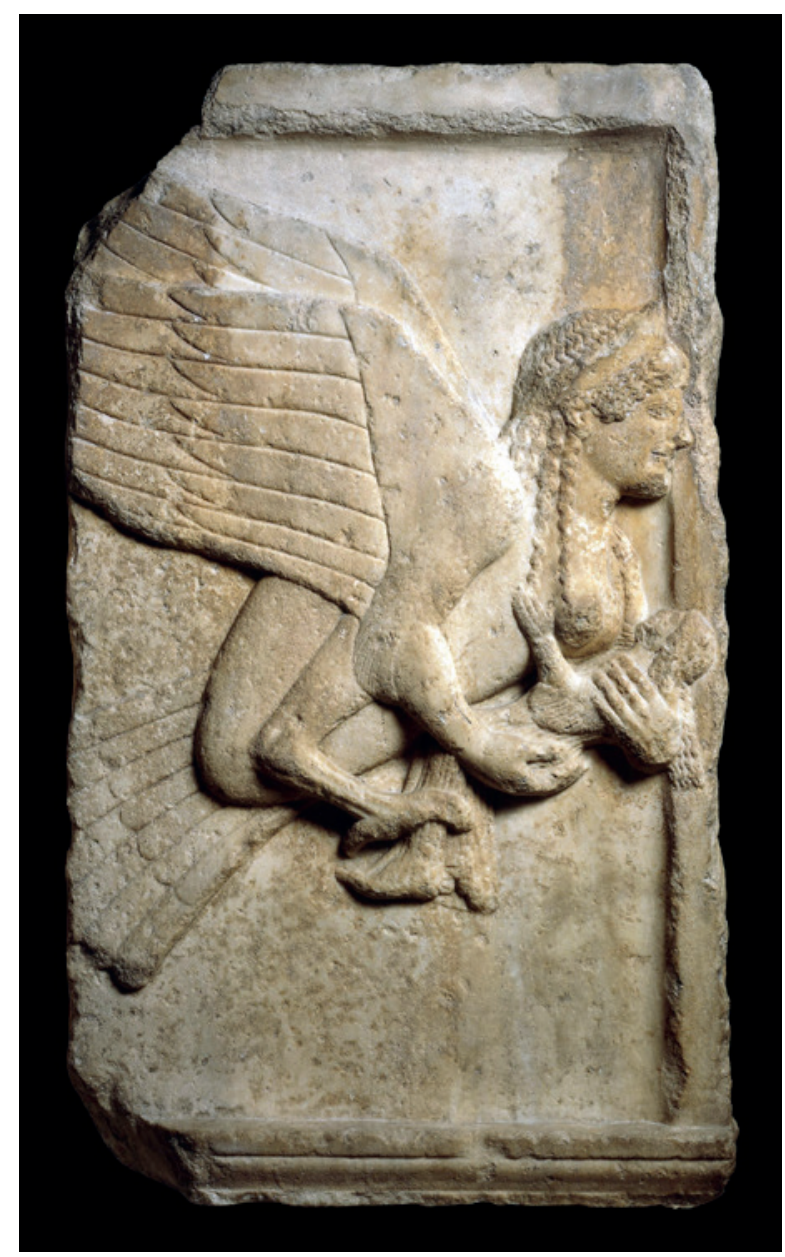

Figura 14. Monumento de las Arpías de Xanthos con el traslado del alma de una difunta. British Museum (Foto (C) Trustees of the British Museum Ref. AN32808001).

de arpías para estos pájaros con cabeza femenina que transportan a dos mujeres, representadas como miniaturas humanas, procede de la interpretación inicial de esta escena como la del rapto de las hijas del rey Pandareo de Licia que llevaron a cabo estos monstruos. Con posterioridad se han clasificado correctamente como sirenas que se llevan las almas de dos difuntas relacionadas con la familia enterrada en este monumento ${ }^{4}$ (Cook 1976, fig. 55).

La presencia de arpías no ha sido considerada en la escultura ibérica salvo en el caso de Porcuna. La figura que se consideró como tal tiene las alas explayadas y

4. Perseus Digital Library Project. Ed. Gregory R. Crane. Acceso: 1 de septiembre de 2011. Tufts University. http://www.perseus.tufts. edu/hopper/artifact?name=London $\% 20 B \% 20287 \&$ object $=$ Sculpture

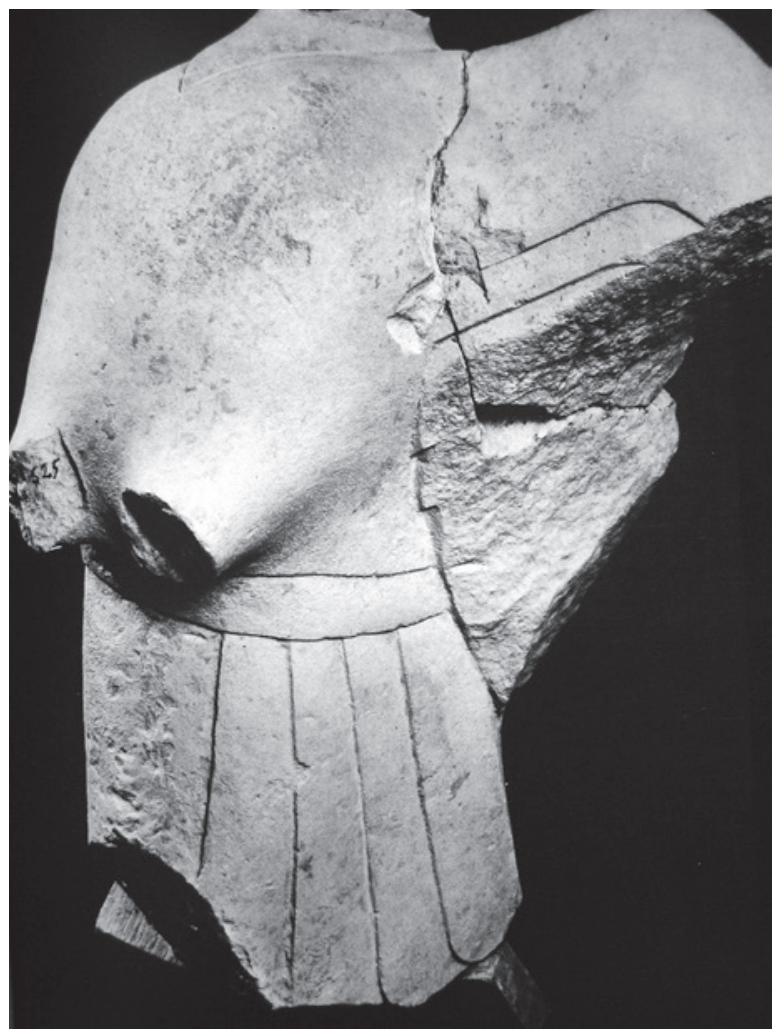

Figura 15. Arpía del conjunto escultórico de Porcuna (Jaén) (Foto González Navarrete 1987).

su cuello se inserta con un resalte en V sobre el cuerpo (fig. 15). González Navarrete (1987: 159-162) consideró que la cabeza sería femenina y por tanto de una sirena, pero el cuello en resalte y no rebajado respecto al cuerpo parece corresponder mejor con una cabeza de ave, lo que convertiría a esta pieza en una arpía. Esta consideración viene condicionada por la seguridad de que algunos de estos seres infernales debieron representarse en las escenas de combate entre guerreros. Ya Blanco Freijeiro (1988, fig. 6) hizo esta conexión, comentando la presencia de unas patas de ave sobre el guerrero muerto, a lo que habría quizás que añadir, siguiendo las características de los escultores de Porcuna, que las marcas incisas que presenta el guerrero bajo estas patas podrían ser de los picotazos del ave. Debemos recordar igualmente que en el conjunto de Porcuna hay otro pájaro, clasificado por González Navarrete (1987: 210-211) como posible lechuza, que podría encajar por su tamaño con el que se asienta sobre la víctima, aunque ciertamente no le corresponde (fig. 16).

Uno de los rasgos más llamativos de la figura exenta de sirena o arpía de Porcuna es que tiene una 

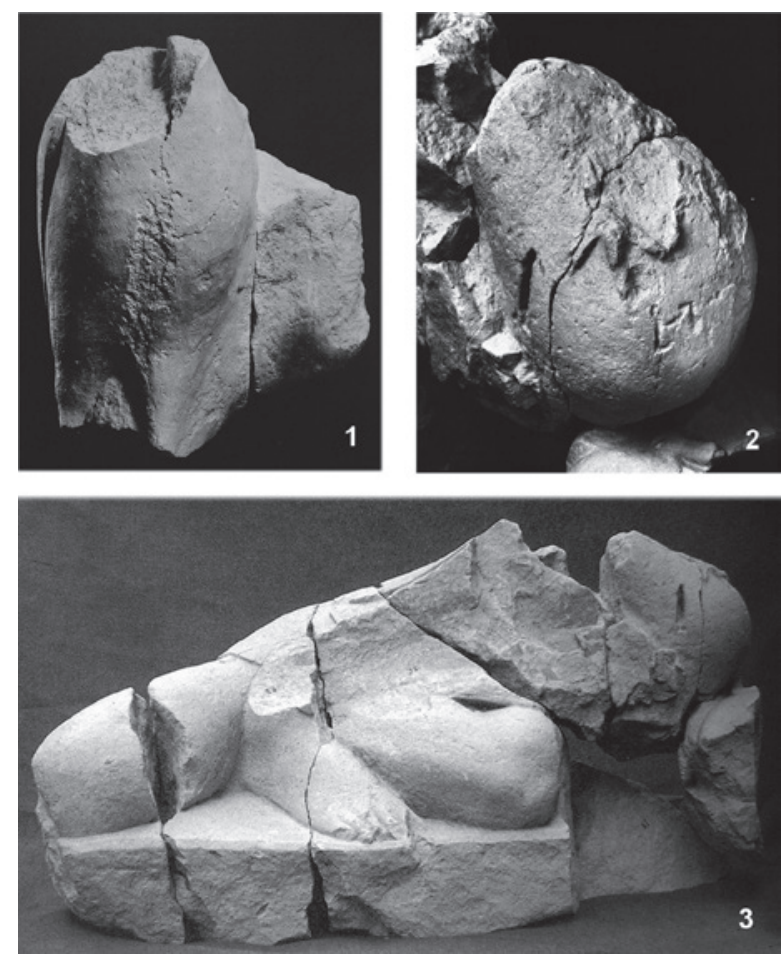

Figura 16. Porcuna (Jaén). 1. Escultura interpretada como lechuza; 2-3. Personaje abatido en combate con restos de garras de ave e incisiones sobre el hombro, posible evidencia de picotazos. (Fotos González Navarrete 1987).

ancha banda en su cintura, de la que salen cuatro pliegues a cada lado, dejando el frente libre. Como señaló González Navarrete (1987: 160), la configuración de estos pliegues corresponde a la de unas alas pegadas al cuerpo, con sus extremos redondeados. La gran fractura que sufrió la pieza por este lado impide ver su conexión con el ala, con la que seguramente existiría una continuidad. En todo caso, estas alas plegadas dan la sensación de un faldellín, acercándose a la idea que se representa en la figura femenina que precede a la esfinge de Elche.

Sin embargo, en este último caso, la esfinge no se representa en vuelo, ni siquiera en una actitud próxima a remontarlo, aunque la elevación del vientre puede ser una indicación en este sentido. Se aproxima así al carácter básicamente estático que muestran otros ejemplares de esfinges ibéricas, también echadas, como las de El Salobral, Bogarra o El Macalón. Otros casos, como las esfinges sentadas de Agost (Olcina Doménech y Ramón Sánchez 2009) o las sirenas de Corral de Saus o El Monastil (Izquierdo 1999), permiten apreciar que su sentido vehicular quedaba implícito en su representación.

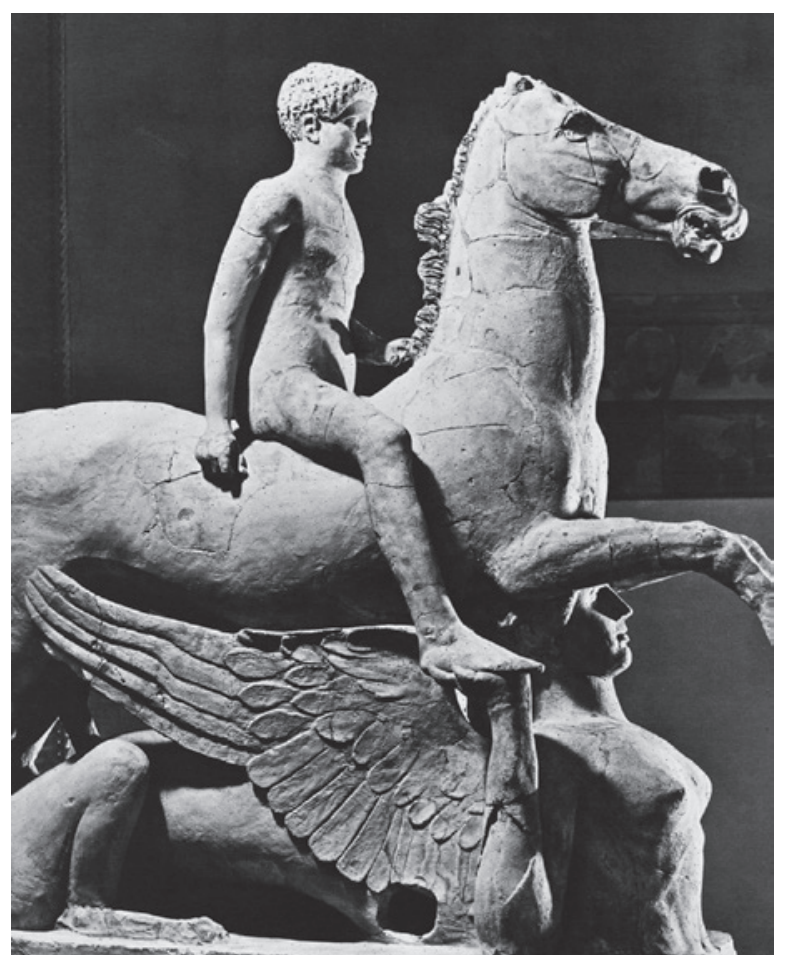

Figura 17. Dióscuro a caballo sobre esfinge. Locri Epizefiri. (Foto (C) Atlas of italian art

http://www.atlantedellarteitaliana.it/).

Su presencia terrenal se relacionaría directamente con su carácter de guardianas y marcadoras de un espacio liminar entre vivos y muertos, moviéndose en un itinerario que para ellas era de doble dirección.

Ya resaltaron Ramos Fernández y Ramos Molina (1992: Lám. XIV) el paralelismo de esta pieza con una gran acrótera de terracota procedente del Templo de Casa Marafioti, en el área de Locri Epizefiri (fig. 17). Representa probablemente a uno de los Dióscuros, que monta sobre un caballo que se apoya sobre una gran esfinge. Esta, con sus manos, aguanta a su vez las palmas de los pies del joven. La delicadeza de la acción, a pesar de su complejidad técnica nos indica el carácter servicial de la esfinge cuando el personaje humano con el que se relaciona tiene un carácter semidivino o heroico.

La esfinge de Elche no ha perdido sus poderosas garras que, aunque esquemáticas, tienen un tamaño considerable. Han adquirido, en todo caso, un cierto carácter humano, al no mostrar con demasiada franqueza las uñas afiladas. Las pulseras, si es que lo son y no recursos iconográficos para indicar la frontera entre brazos y garras, apoyarían esta intención humanizadora. 

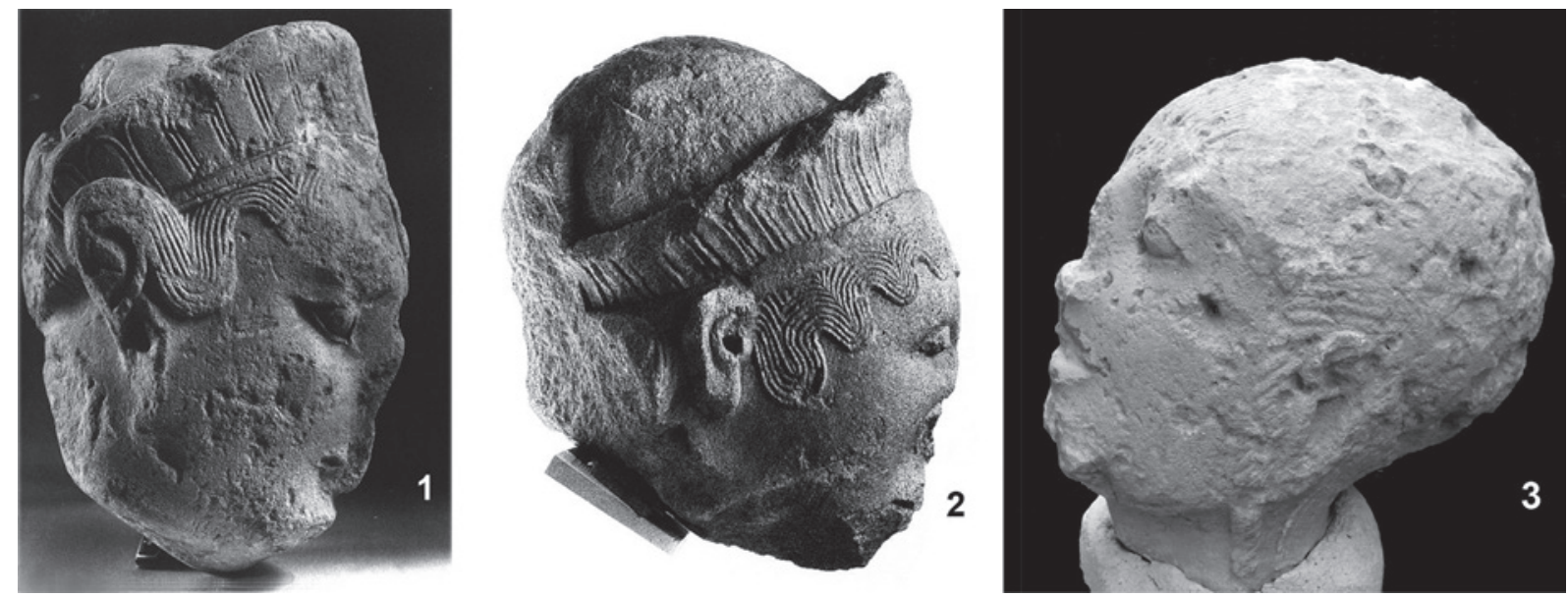

Figura 18. 1. Koré de Alicante; 2. Cabeza femenina de Úbeda la Vieja (Fotos Blech y Ruano 1993); 3. Cabeza de La Alcudia (Foto T. Chapa).

Sin embargo, su poder queda fuera de toda duda. Esta insistencia en la amenaza que puede residir en ellas se aprecia también en la pata trasera de la esfinge de El Salobral conservada en Paris o, mucho más esquemáticamente, en las de El Macalón y Bogarra (Chapa 1980: Láms. V, VI y VII).

La falta de la cabeza es, como se ha dicho, una dificultad importante a la hora de valorar esta pieza, puesto que podría aportar muchos detalles a su carácter. Sus mechones, que caen oblicuamente sobre el cuello, nos vuelven a recordar en cierta medida a la esfinge de El Salobral, distanciándose de otras, como las ya citadas de Bogarra y Agost, o la sirena de Villaricos (Almagro-Gorbea y Torres 2006), cuyos tirabuzones, en todos los casos, adquieren notable relieve, siendo casi siempre múltiples. Se asemeja así su peinado al de ciertos jóvenes ibéricos, hombres y mujeres, que recogen sus largos cabellos en dos gruesas trenzas, desapareciendo éstas al llegar a la edad adulta, como nos muestran los exvotos de bronce de los santuarios de Jaén (Rueda 2007: 232).

Se ha propuesto reiterativamente que ciertas cabezas femeninas con peinado de mechones ondulados sobre la frente y tocado de diadema alta podrían corresponder a esfinges. Es el caso de la koré de Alicante (Verdú 2009, con bibliografía anterior) o de la cabeza de Úbeda la Vieja (Blech y Ruano 1993: fig. 1). La primera no muestra indicios de mechones sobre su cuello, pero en la segunda pieza se aprecia el arranque de varios tirabuzones. Como hemos visto, esto no indica necesariamente que se trate de una esfinge y no de una figura humana, pero la primera opción no puede descartarse. En todo caso, los raros ejemplos de esfinges ibéricas de piedra que conservan tanto el cuerpo como la cabeza (Agost, Bogarra) nos señalan la presencia de una diadema asociada al peinado de mechones más gruesos, aunque aquella nunca alcanza la misma envergadura de Úbeda la Vieja o Alicante (fig. 18).

Ignoramos si las cabezas de esfinge asociadas a los mechones finos, como es el caso de la de Elche, tendrían el mismo tocado o si este sería más sencillo. La única cabeza humana que presenta este tipo de mechones procede de La Alcudia y se conserva en su Museo Monográfico. Se trata de una figura de pequeño tamaño caracterizada por su sonrisa y sus ojos rasgados. Su peinado consiste simplemente en mechones finos que se muestran en el flequillo y bajo un gorro liso que parece cubrir la parte posterior de la cabeza. En el mismo sector del yacimiento, situado en el extremo oriental, se recuperaron el cuerpo de una leona con el costillar marcado, un tronco de toro, una cintura correspondiente a un varón y varios relieves (Ramos Fernández y Ramos Molina 2004: 136-137). Como en los casos anteriores, pudiera tratarse de una cabeza humana, pero tampoco es incompatible con la de una esfinge.

Junto con las garras y la envergadura de su cuerpo, el ala del ejemplar del Parque Infantil de Tráfico fue otro de los elementos más llamativos de esta pieza. Surge de la mitad superior del brazo y continúa la línea del omóplato, para elevarse sobre el cuerpo definiendo una curva que sólo queda esbozada, a falta de su extremo. Consta de dos cuerpos paralelos longitudinalmente y muy claramente definidos. Uno de ellos es liso, y llega hasta el final del ala. En principio podría pensarse en una decoración pintada, de tipo plumón, como sucede en el pínax de Ibiza (Blázquez 1956) o en 

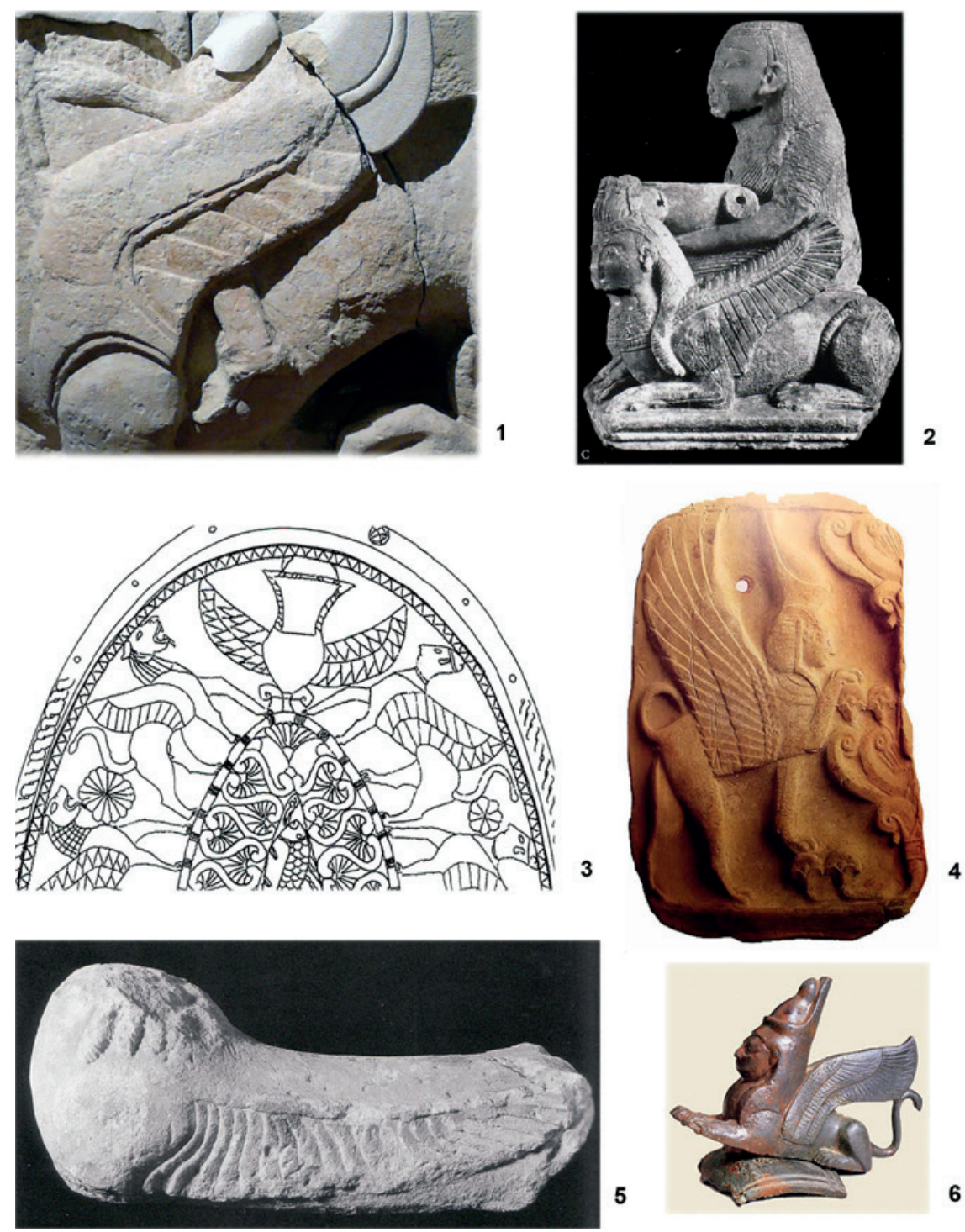

Figura 19. 1. Detalle del ala de la esfinge de Elche (Foto T. Chapa); 2. Estatuilla femenina entre esfinges de Galera (Granada) (Foto M.A.N.); 3. Dibujo parcial de la Fuente incisa de El Gandul (Sevilla) (a partir de Fernández Gómez 1989); 4. Pinax con esfinge de Ibiza (Foto Fontan y Le Meaux 2007-2008: catalogue 238); 5. Ala de sirena de Villaricos (Foto M.A.N.); 6. Esfinge en bronce de Cástulo (Jaén) (Foto Centro Andaluz de Arqueología Ibérica). las esfinges de marfil, tanto próximo-orientales (Barnett 1977: 47) como griegas arcaicas. Es el caso del ejemplar de Perachora, que repite el diseño longitudinal del ala con cuerpos paralelos, pero decorando con círculos el primero de ellos (Osborne 1998, Lám. 24). En el caso de Elche no hemos podido apreciar a simple vista indicios de pintura, aunque Ramos Fernández y Ramos Molina (1992: 35) señalan que conservaba restos de color rojo. Este hecho coincide con otros ejemplares, como las esfinges de El Salobral, con restos bien documentados (Navarro Gascón 2001).

En la Península Ibérica las alas largas, de cuerpos paralelos y plumas cortas, tienen su mayor desarrollo en época preibérica (fig. 19). Este es el modelo seguido en las esfinges que flanquean a la dama sedente de Galera (Olmos 2004), en las que el primer cuerpo se decora finamente con trazos horizontales y un plumón perlado, o en la "sirena" de Villaricos (Almagro-Gorbea y Torres 2006), cuyas plumas surgen también de un cuerpo liso. El ala de la esfinge de Elche surge y cubre el hombro del animal, mientras que en los casos antes citados y en otros que siguen modelos orientales, como la esfinge de bronce de Cástulo o las que decoran la bandeja de El Gandul (Jiménez Ávila 2002, fig. 245), las alas suelen dejar libre esta zona. Sin embargo, este no era un rasgo normativo, puesto que en otros ejemplares del mismo contexto general podemos ver cómo las alas cubren los hombros y tienen la misma 
configuración formal. Así sucede en los grifos pintados sobre el pithos de Carmona (Belén et al. 1997: figs. 33-34, foto 13), en el que decora un vaso del conjunto de Lora del Río (Remesal 1975: fig. 1), o en los patos que flanquean la figura femenina central del Bronce Carriazo (Maluquer 1957).

Tampoco hay que olvidar, y menos en el caso que estudiamos, la relación de las esfinges con las divinidades femeninas y su asociación directa con los tronos en los que se sientan. De alguna forma, también en estos casos se convierten en soportes divinos y por ello podemos vincularlas a la figura apoyada en las patas delanteras del ejemplar de Elche. En el contexto ibérico el caso más conocido es el de la figura de Galera, en el que las esfinges se nos representan como animales "reales", y no meras decoraciones en relieve de un trono, aunque su presencia como soportes iconográficos también es muy frecuente. Así sucede en los llamados "tronos de Astarté" de ámbito fenicio, que alcanzan épocas relativamente tardías (Delcor 1983) (fig. 20).

La proximidad entre las esfinges y las figuras divinas o humanas de la más alta condición se evidencia también en el caso de Porcuna, donde una esfinge en pie se adorna con vestimentas que caen del cuello hasta el suelo, perfilando el interior de las patas delanteras (fig. 21). La tela surge de dos adornos situados a los lados del cuello y una tira oblicua, que queda prendida en el lado derecho, impide que la vestimenta se abra y conforma una especie de escote en pico. Se conserva algo mejor este lado, apreciándose que sobre el final del hombro hay una línea en resalte curvo que daría paso al ala. Blanco Freijeiro (1988: 208-209 y fig. 3) propuso que el relieve triangular, en forma de "cartabón", que se sitúa bajo el inicio del ala de la esfinge sería un posible apoyo pensado para dejar la figura exenta, cosa que al final no se completó. Su morfología, sin embargo, permitiría relacionarla con un ala plegada, aunque esta posición sería muy inusual.

La vestimenta de la esfinge se remata en borlas, aunque los pliegues del lado izquierdo son diferentes en su relieve y morfología respecto a los del lado derecho. Estos remates se aprecian en algunas de las figuras humanas del mismo conjunto, aunque la forma se acerca más a la del "sacerdote" que a la de la "sacerdotisa", por el hecho de que los pliegues de la esfinge son verticales, como en el primero de estos personajes, mientras que los de la escultura femenina son oblicuos. La esfinge de Porcuna esta tallada por ambas caras, y su plinto se desarrolla también por igual, aunque en el lado izquierdo parece que el resalte triangular apuntado no se habría marcado. Este detalle y el hecho de que el

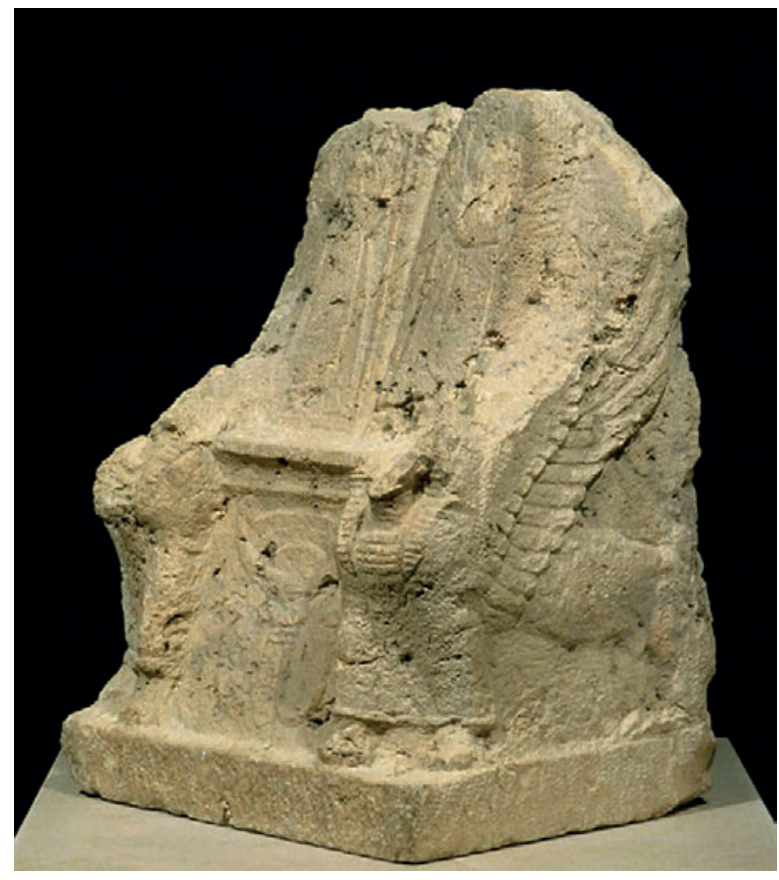

Figura 20. Trono votivo de Astarté flanqueado por esfinges procedente de Khirbet et-Tayibeb (Tiro, Líbano), s. II a.C. Museo del Louvre AO4565 (Foto (C) Musée du Louvre /C. Larrieu).

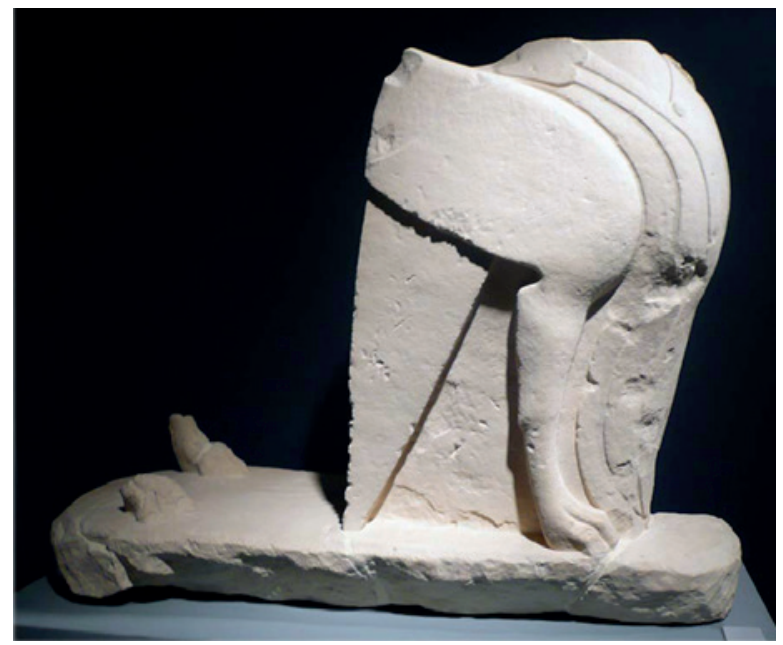

Figura 21. Esfinge de Porcuna (Jaén) (Foto Museo de Jaén).

cuello muestra signos evidentes de girar hacia la derecha, indicaría una visión preferente por este lado. La humanización y dignificación de su cuerpo con las vestiduras indica, como sucedía en Egipto, una estrecha asociación con las divinidades y las élites dominantes. La figura ya citada de Galera nos lo muestra con claridad, al decorar los cuellos de las esfinges con collares 
de complejos dibujos (Almagro Gorbea y Torres 2010: 193) y sus grupas con cintas, como si todo su cuerpo felino estuviera vestido con una túnica de remates decorados. Quedan finalmente por analizar los motivos circulares incisos que la esfinge lleva marcados sobre su anca izquierda (fig. 11). Su morfología no puede ser definida con detalle, debido a la costra que los cubre parcialmente y que impide su visualización completa. Este hecho y la erosión apreciable tanto en las incisiones como en las puntuaciones que a ellas se asocian, permiten considerar que estos motivos son contemporáneos al uso de la escultura, pero complican un estudio detallado de las mismas.

Ya hemos reconocido en otros trabajos el empleo de incisiones finas sobre las esculturas ibéricas, apenas visibles para un espectador no advertido o sin la iluminación precisa (Chapa et al. 2009 a y b). En el caso de Elche los motivos son discretos pero apreciables, y teniendo en cuenta la presencia en ciertos puntos de la estatua, como el pie del jinete, de otras incisiones que pudieran delimitar elementos de vestido rellenos de pintura, no podemos descartar que estos motivos circulares también fueran pintados, haciéndose aún más evidentes. La falta de incisiones u orificios más profundos impiden pensar en que fueran el asiento de apliques metálicos, como debió suceder en el "torito" de Porcuna (Blanco Freijeiro 1960: 38).

La existencia de motivos incisos y/o pintados en los omóplatos y ancas de los animales es un hecho frecuente, especialmente en el arte del Próximo Oriente y Orientalizante en general. La expansión del motivo denominado "flame and frond" (Herrmann 1989; 2000: 13) fue general en todo el Mediterráneo, y la Península Ibérica no fue una excepción (Almagro-Gorbea 2008: 412). Además de los animales "marcados" de los marfiles orientalizantes andaluces y extremeños, tenemos también evidencias similares en la decoración de las cerámicas de carácter ritual, como las de Montemolín (Chaves y De la Bandera 1986).

Marcas naturales o añadidas debieron tener un significado importante en su asociación con los animales, ya que en ocasiones se relacionan con símbolos divinos. En leyendas antiguas, como la de la fundación de Tebas, el oráculo de Delfos indica a Cadmo que siga a una vaca y construya una ciudad allí donde el animal caiga exhausto. El héroe escoge para ello a la que llevaba en sus flancos un disco blanco que identificó con la luna (Grimal 1993: 79 “Cadmo”) y el animal le condujo a través de Beocia hasta el lugar donde debía ser levantada la ciudad. Como también recuerda Blanco Freijeiro (1961-1962: 187) al Minotauro cretense se le denominaba "Asterios", y las estrellas que le recubrían se representaban como flores. Aunque presentan segmentos circulares, los motivos incisos de la esfinge de Elche no pueden interpretarse como rosetas o motivos florales, ni tampoco como ruedas, aunque no sería descartable que sugieran el giro que engendra movimiento, y por extensión el tránsito astral.

\section{La diosa del vestido de alas}

La iconografía de la figura femenina que encabeza el grupo escultórico se relaciona con las imágenes antropomorfas aladas que desde mediados del II milenio a.C. se asocian en Egipto al mundo de ultratumba (López Grande 2003). Las diosas Maat, Nut, Isis y Neftis, entre otras, ofrecían protección al difunto bajo sus alas y le garantizaban la vida eterna. Una versión singular de estas representaciones fueron los vestidos que incorporan las alas plegadas sobre la túnica, bien caídas desde la cintura y cruzadas sobre la parte inferior del cuerpo, o bien envolviéndolo en capas. Desde la dinastía XVIII esta indumentaria divina fue compartida por las madres, esposas e hijas del faraón que tenían la condición de damas sagradas (Idem: 43-55) (fig. 22), lo que hace que sea imposible conocer la identidad y naturaleza divina o mortal de los personajes en ausencia de inscripción que las acredite (Robins 2008: 129).

La iconografía de las deidades con alas, femeninas y masculinas, pasó de Egipto al Próximo Oriente entre fines del II y principios del I milenio a.C. y desde allí los fenicios lo difundieron en su expansión por el Mediterráneo (Keel 2007: 186), conservando su relación con el ámbito funerario. No se excluye la transmisión directa desde territorio egipcio a Cartago (López Grande 2003: 133-134), donde el motivo aparece por primera vez en la decoración de un peine de marfil del siglo VI a. C. (López Grande y Trello 2004: 341, fig. 6), aunque el tipo de las alas pegadas sobre el cuerpo como parte del vestido sólo se conoce con seguridad a partir del siglo IV a.C., si bien pudo crearse con anterioridad (Aubet 1976: 74). El ejemplo más renombrado es sin duda el sarcófago de la necrópolis de Sainte-Monique fechado en los siglos IV-III a.C. Las alas salen de la cintura y envuelven las piernas de la figura femenina esculpida en la tapa, dejando ver el borde inferior de la túnica a la que se superponen y los dedos de los pies (Sznycer 1995: 101). De personalidad controvertida por ser anónima -sacerdotisa revestida con atributos divinos para unos, la efigie de la diosa Tinnit, para otros-, la talla aúna influencias estilísticas egipcias y griegas, 


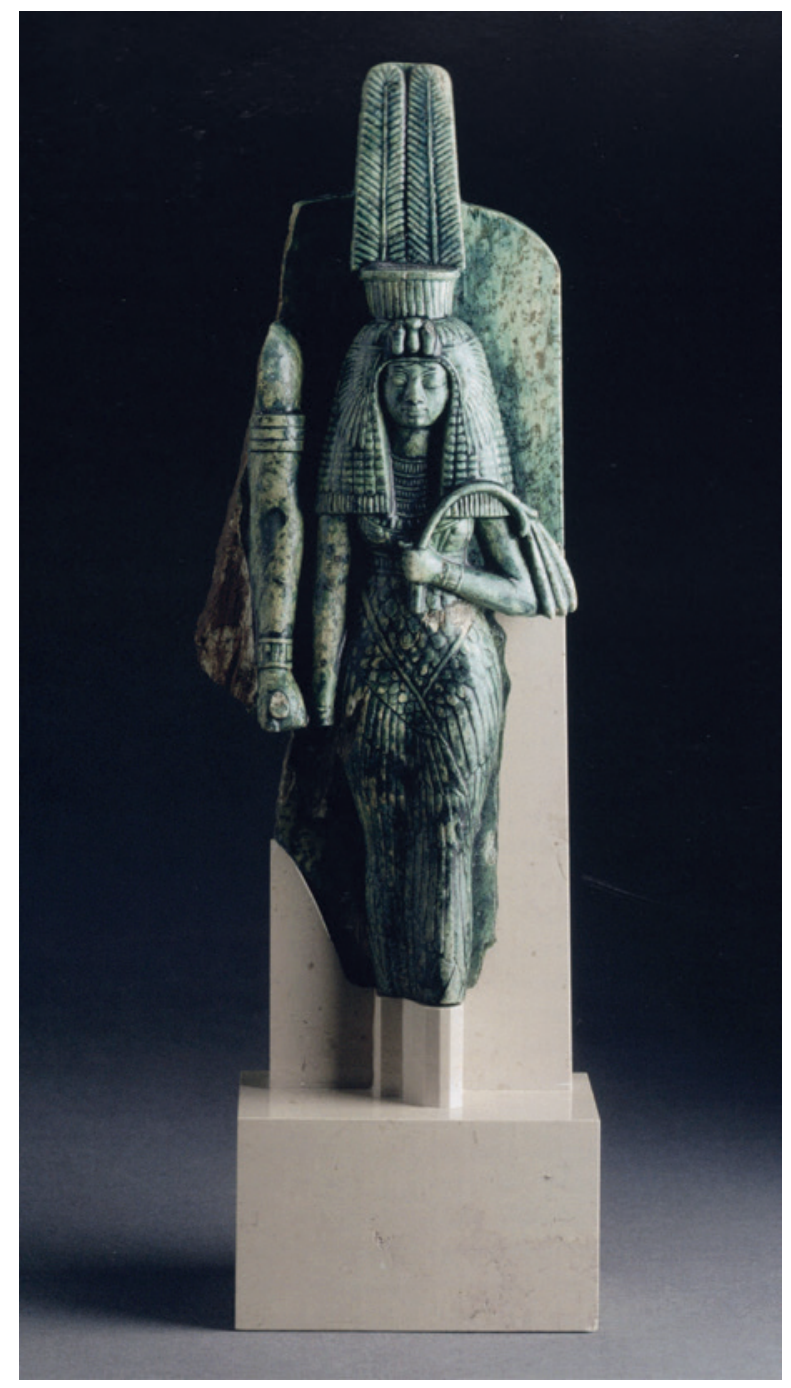

Figura 22. La reina Tiy con vestido de alas (Foto Chr. Ziegler 2008: 19)

como es común en el arte fenicio y púnico. Más popular parece haber sido la falda envuelta por varias capas de alas, que encontramos en joyas (Quillard 1987: 196197, pl. XXIII: 311 y XLI: 4), terracotas (Aubet 1976: 73-74, lám. V) y navajas de afeitar (Marín Ceballos 1987: 68, fig. 9), procedentes de contextos sepulcrales con cronología comprendida entre el IV y el II a.C. Con frecuencia el vestido de alas se asocia a imágenes leontocéfalas, asimismo deudoras de la iconografía religiosa egipcia (Marín Ceballos 1995). A unos 60 km de la capital tunecina, en Thinissut, un santuario rural en el que se daba culto a Tinnit desde época tardo-púnica (III-II a. C.) (Bullo y Rossignoli 1998), se hallaron fragmentos de varias estatuas femeninas en terracota de tamaño casi natural, con cabeza leonina y falda estrecha con dos capas de plumas sobrepuestas. Las piezas se suelen datar en el siglo I d.C., aunque podrían ser más antiguas de acuerdo con las fechas que ahora se proponen para el inicio de la actividad cultual en el complejo sacro. En cualquier caso, esta iconografía híbrida mantuvo plena vigencia después de la imposición del poder romano sobre la antigua colonia cartaginesa y su territorio. Un personaje femenino leontocéfalo vestido con falda de plumas, figura en un denario acuñado por Q. Caecilius Metellus Pius Scipio a mediados del I a.C. El tipo monetal se acompaña del rótulo $G T A$ en el que se ha leído G(enius) T(errae) A(fricae), interpretando que se refiere a Tinnit, la antigua divinidad poliada de Cartago, convertida ahora en patrona de la provincia africana (Marín Ceballos 1995: 837-840).

En el ámbito semita extremo occidental, diosas con uno o dos pares de alas desplegadas están representadas sobre distintos soportes de época orientalizante, sin ser un motivo frecuente (Le Meaux 2010: 65-68 y 93), pero como en el resto del Mediterráneo, el vestido de alas sólo está documentado en época púnica. Los mejores ejemplos nos lo ofrece la colección de exvotos de la Cueva de Es Culleram, al NE de la isla de Ibiza, un santuario consagrado a Tinnit, según consta en una inscripción del II a. C. que la invoca como "poderosa y Gad", resaltando su carácter de divinidad poliada (Marín Ceballos et al. 2010: 155). El conjunto más representativo entre las terracotas procedentes del yacimiento son cerca de 1.000 figuras femeninas de forma acampanada revestidas con dos grandes alas, generalmente de dos capas de plumas, que cubren el cuerpo a modo de manto. Muchas presentan una flor de tres pétalos sobre el pecho, por lo común identificada como loto (Le Meaux 2010: 102-103) (fig. 23), y con menor frecuencia motivos astrales, con o sin caduceo. Para Aubet (1976: 76-77) esta singular versión del personaje femenino con vestido de alas, prácticamente desconocida fuera de Ibiza, es una recreación púnica con rasgos originales respecto a los modelos egipcios que la inspiraron y a la coroplastia griega siciliota cuya influencia es igualmente notoria (Marín Ceballos et al. 2010: 142). Lamentablemente, la falta de contexto estratigráfico impide datar con precisión estas figuras acampanadas. Las fechas de los siglos IV y III a.C. propuestas por Aubet (1976: 66) son posibles, pero en opinión de Ramón (1982: 20-21) la mayor parte de las piezas deben corresponder a la etapa de apogeo del santuario, que se desarrolla entre el siglo III y mediados del II a.C.

Los ejemplos comentados, principalmente los de Thinissut y Es Culleram por estar refrendados por 


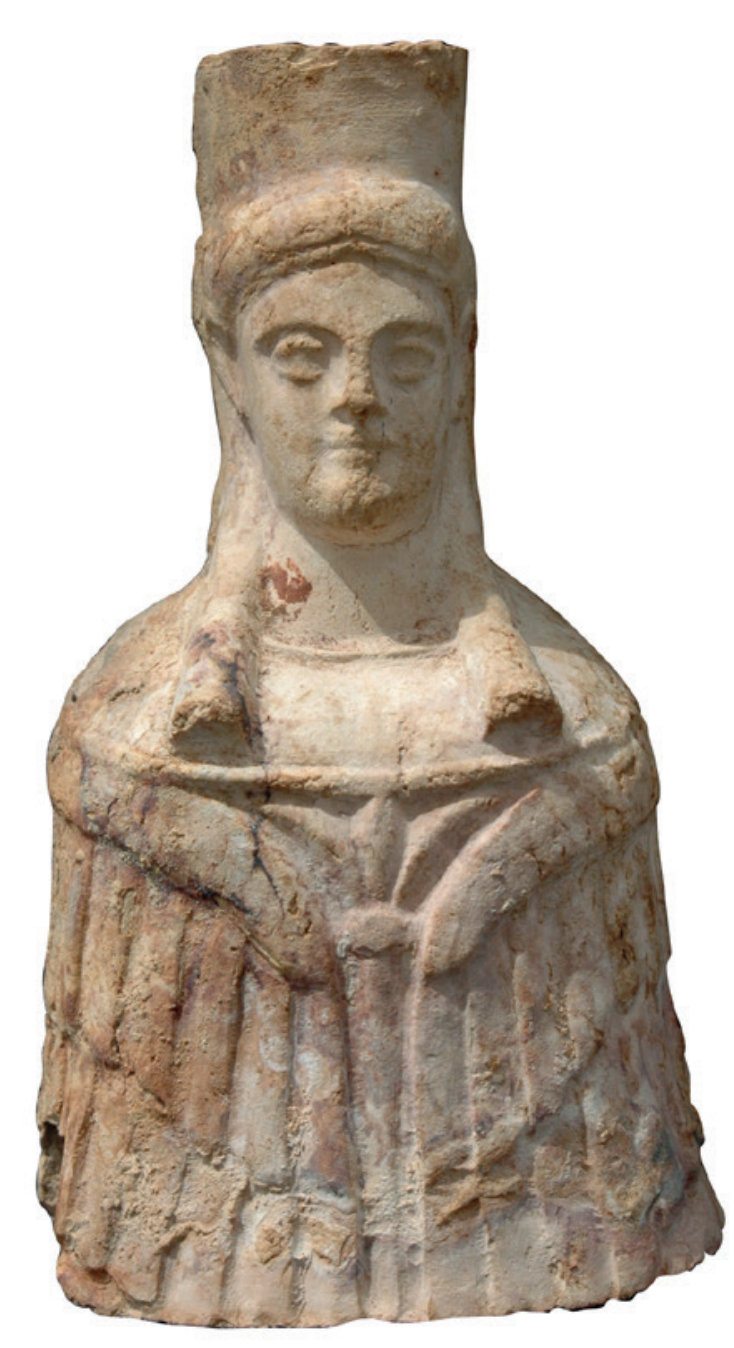

Figura 23. Terracota de la Cueva de Es Culleram (Ibiza) (Foto cortesía del Proyecto “Tinnit en Ibiza”, HUM 2007/63574).

testimonios epigráficos, prueban la relación del vestido de alas con la diosa Tinnit en el ámbito púnico del Mediterráneo centro occidental. Sin embargo, no podemos concluir de ahí que fuera una iconografía canónica de la diosa, que parece que nunca tuvo, sino una forma de expresar una faceta concreta de su compleja personalidad. Tampoco fue la única divinidad semita que usó este tipo iconográfico, porque algunos documentos nos muestran en la misma imagen a distintas deidades con faldas de alas, como el escarabeo de Tharros en el que dos personajes femeninos de cabeza felina vestidos de ese modo, flanquean a un tercero, asimismo de cuerpo híbrido, pero desnudo y con alas desplegadas (Marín Ceballos 1995: 829, fig. 1). Astarté y Tinnit compartieron funciones, iconografía y lugares de culto, de Oriente a Occidente, a lo largo de gran parte del I milenio a.C. (Hvidberg-Hansen 1979; Lipinski 1995: 199-215; Bonnet 1996). Tan estrecha es la relación entre ambas que para algunos autores (Lipinski 1995: 205), Tinnit no fue más que una hipóstasis de Astarté, "la forma púnica" de la gran diosa semita del I milenio, en palabras de G. Ch. Picard (1954: 65). Aunque no parece que ninguna de ellas llegara a suplantar a la otra, los fenómenos de interpretatio de que fueron objeto, reflejan de modo inequívoco la afinidad que se les reconocía (Bonnet 1996: 97-108). Estas asimilaciones las presentan como diosas curótrofas, astrales, marinas, políadas y ctonias, sin que podamos establecer con claridad cómo fueron evolucionando con el tiempo tan variadas funciones, que se traducen en diferentes tipos iconográficos, muchos de ellos igualmente compartidos por ambas, que resaltan una u otra dimensión de sus complejas naturalezas y las dotan de una imagen multiforme. Tinnit es una diosa de origen oriental conocida a través de la epigrafía al menos desde el siglo VIII a.C., pero su promoción en el ámbito semita norteafricano a partir de fines del V a.C. no supuso la anulación de Astarté, que está muy presente en la onomástica cartaginesa y todavía se le rendía culto después de la conquista por los romanos de los antiguos dominios púnicos (Bonnet 1996: 97-108). Una inscripción de la localidad libia de Mididi, en Túnez, grabada en caracteres neopúnicos y fechada en el I a.C., recoge la dedicación por los ciudadanos del lugar de un templo a Ashtart, "esposa de Baal". Y a la inversa, la epigrafía monetal también documenta el culto de Tinnit en Oriente, hasta el siglo II d. C. Son, pues, diosas distintas pero muy próximas. Su estrecha relación se expresa en los documentos epigráficos mediante fórmulas de sincretismo o de parentesco. En la famosa inscripción hallada en Sarepta, fechada en el VII a.C., se le dedica una estatua a Tinnit-Ashtart, como si se tratara de una única entidad divina. El teónimo compuesto es una forma sincrética que Xella (1990: 174-175) considera indicativa de la estrecha relación entre las dos diosas, una unión que enriquecía su naturaleza y ampliaba sus respectivos campos de acción, sin que por ello perdieran su individualidad ni la facultad de mostrarse de forma independiente (cf. Hornung 1999: 88-90). C. Bonnet (1991) ha llegado a sugerir una relación fraternal entre ambas, basándose en una inscripción bilingüe greco-latina hallada en Deir el-Qal'a, en la montaña libanesa. Se fecha en el II-III d.C. y menciona a Hera-Juno, que la autora cree interpretatio de Astarté, y a Hera Néôtera que en la inscripción latina se convierte en Caelestis, la diosa 
romana que encubre, en opinión mayoritaria, a la Tinnit púnica (Cadotte 2007: 65-81), que aquí aparece como hermana menor, en una relación de parentesco que recuerda a las egipcias Isis y Nephtys con las que tanto tenían en común. Resulta sugestivo evocar aquí a la pareja de diosas leontocéfalas con falda de alas que figura en un anillo de oro hallado en la necrópolis cartaginesa de Sainte-Monique, fechado en el III a.C. (Quillard 1987: 196, lám. XXIII: 311), por más que no pueda asegurarse que sean las diosas semitas hermanadas.

La historiografía española reciente asume que el culto de Astarté, introducido por los fenicios durante la etapa colonial, continuó también en Iberia al menos durante los últimos siglos prerromanos, quizá en sincretismo con Tinnit que parece omnipresente en el sur y sureste peninsular a partir del siglo IV a.C. y, sobre todo, en la época de dominio bárquida (Ferrer 2002: 209; Moneo 2003: 431). Esta opinión, acorde con lo que se sabe del desarrollo histórico del culto de ambas diosas en el norte de África, no ayuda a resolver el problema de la identidad de las imágenes, de ahí que las opciones vacilen a favor de una u otra divinidad sin criterios claros, con la complicación añadida de los sincretismos y superposiciones que debieron producirse en las distintas situaciones de contacto cultural. Es el caso de la figura femenina del grupo escultórico de Elche, que unos identifican con Astarté (Prados 20022003: 216) y otros con una deidad local asimilada a Tinnit (Marín Ceballos 1987: 66 y 68), o con una ambigua Astarté-Tinnit igualmente sincretizada (Poveda 1999: 38-39) que se justifica en la dificultad de diferenciar los rasgos característicos de una y otra. El vestido de alas y la flor de tres pétalos que cubre su pecho, la caracterizan como divinidad a la vez urania y del inframundo, guía segura en el viaje al Más Allá, protectora en el reino de la muerte y garante del retorno a la vida, de la regeneración simbolizada en la flor de loto. El tamaño desmesurado de la mano derecha habla de la generosidad de la diosa y de su compromiso con los que en ella confían. La estética y el simbolismo de la imagen son púnicos y posiblemente están inspirados en una estatua de culto. La supremacía de Tinnit en el mundo púnico, su reiterada y ubícua presencia en el sureste peninsular a partir del siglo IV a.C. (Marín Ceballos 1987) y la forma con que se expresa su condición de diosa alada, bien conocida como tipo de la diosa cartaginesa, inclinan nuestra opción a su favor. En la transmisión del modelo pudo haber intervenido Ibiza, que mantenía relaciones comerciales estrechas con las comunidades iberas del área contestana. La arquitectura religiosa (Prados 2002-2003: 207), la imagen antropomorfa y simbólica de una diosa sobre cerámica (González Alcalde 1997), los pebeteros en forma de cabeza femenina (Moratalla y Verdú 2007: 344-346) y la interpretatio latina de las devociones de la ciudad (Poveda 1995), son otros testimonios de la influencia púnica en la religiosidad de la antigua Ilici entre el siglo III a. C. y la etapa romana. Como se ha señalado (Bendala 2005, entre otros), la impronta púnica de la cultura ibérica contestana, muy acusada en el entorno del antiguo golfo ilicitano, no puede entenderse sin considerar la presencia estable de población de origen púnico en la zona y una larga etapa de interacción entre iberos y semitas. Las tradiciones púnicas, que se afianzan en la zona sobre todo en la etapa cartaginesa, arraigan sobre un sustrato fenicio arcaico bien documentado en los últimos años (Sala Sellés 2004).

\section{CONCLUSIONES}

La presencia de la esfinge no es una novedad entre las manifestaciones escultóricas ibéricas, pero la pieza encontrada en el Parque Infantil de Tráfico de Elche presenta una asociación singular con dos figuras, una de ellas humana y otra divina. Esto la convierte en un caso único, como ha reconocido unánimemente la investigación, aunque son muchos los interrogantes que todavía presenta y que distan mucho de poder resolverse. La interpretación del contexto arqueológico llevó a datar la obra en el siglo V a.C. (Ramos Fernández y Ramos Molina 1992: 29), fecha que se avenía bien con los rasgos estilísticos antiguos que presenta la talla de las alas del animal, pero el modelo iconográfico de la diosa con vestido de alas, en sus distintas versiones, no se conoce en el mundo púnico antes del siglo IV a.C., como bien señaló Marín Ceballos (1987: 66). Estas fechas más recientes coinciden con una época de crecimiento económico en la Contestania ibera que potencia las relaciones de intercambio, los contactos y los cambios sociales. Es también la etapa de auge de la producción escultórica (Sala Sellés 2007: 52) que ahora incorpora corrientes estéticas y modas de procedencia púnica (Prados 2007). Muchas de estas novedades debieron llegar a través de Ibiza, entre otras la iconografía de Tinnit alada que adopta la diosa psicopompa del grupo para el viaje a la eternidad.

Como se ha señalado al comienzo, la esfinge se encontró partida en dos grandes trozos que se incluyeron en un murete ovalado junto a otros fragmentos de esculturas ibéricas. Entre ellos, un toro, una garra de esfinge, patas y un posible resto de cuadrúpedo, parte de 

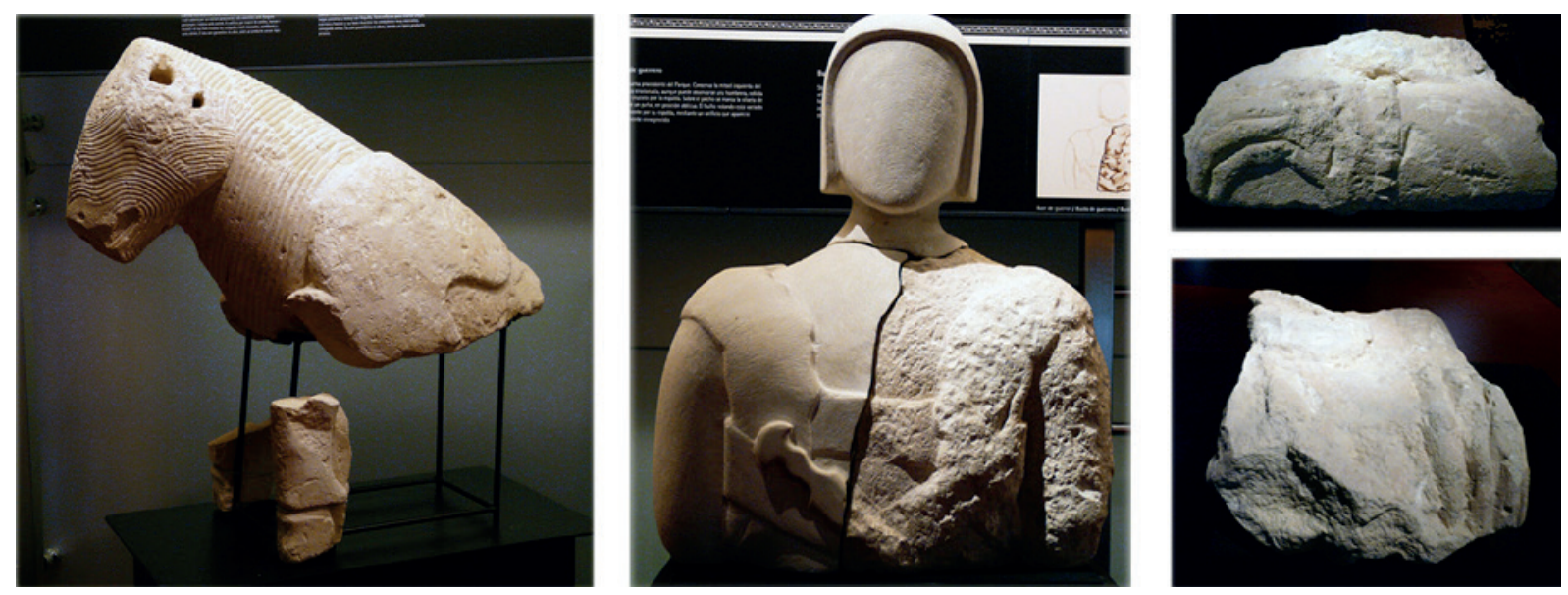

Figura 24. Fragmentos escultóricos descubiertos en el área del Parque Infantil de Tráfico de Elche (Fotos T. Chapa).

un faldellín y un torso masculino con la espalda vaciada. Es de suponer que en el lado oriental del "témenos", destruido por la construcción romana, hubiera otras piezas, además de las que pudieran completar a las ya citadas.

La asociación de estas esculturas supone un caso excepcional en la estatuaria ibérica. Dado que el lado derecho de la esfinge corresponde a un bloque informe o muy dañado por los golpes y la erosión, se ha supuesto que formaba parte del monumento de sillería cuyos bloques fueron recuperados en los muros de la villa romana, situándose su emplazamiento original inmediatamente al norte del "témenos". Aunque el rebaje interpretado como asentamiento de los sillares de base indicaba unas dimensiones de 3,30 $\mathrm{m}$ de lado, las dimensiones que se proponen para la base del monumento no superan $1,90 \mathrm{~m}$, reduciéndose a $1,22 \mathrm{~m}$ la longitud del segundo cuerpo. Si la figura de la esfinge estaba preparada para formar parte de la edificación en este nivel y no iba adosada, como se presenta hoy en el Museo, su longitud debería añadirse a la de la pared, acercándose más al tamaño que presenta la huella que habrían dejado los sillares en el suelo. La existencia, además, de una garra que pudiera corresponder a otra esfinge ha hecho pensar en un monumento turriforme con cuatro esculturas de esquina, lo que modificaría la altura y las proporciones del edificio (Prados 2008: 260).

Debemos resaltar, sin embargo, que la morfología comparada de las garras no permite asegurar que se trate de figuras gemelas. La diferencia en la envergadura y la forma de los dedos es suficientemente grande como para atribuirlas mecánicamente a una misma pareja. La garra aislada curva sus dedos, muy simplificados y de limitado relieve, sobre una superficie plana, y apenas los eleva sobre la altura de su pata. Aunque lleva una "pulsera", esta se encuentra dividida en secciones, mientras que en la gran esfinge es lisa. En general, y aunque sabemos que hay diferencias entre esculturas de un mismo conjunto, en este caso el tipo de labra y de alisado no presentan afinidades suficientes, por lo que consideramos que pudieron pertenecer a grupos distintos.

También nos vamos a permitir en este trabajo, al menos hipotéticamente, disociar el monumento de sillares respecto a las esculturas recuperadas en el alineamiento. En una primera presentación provisional en el Museo de Elche, la base de la edificación, bastante más ancha que el resto del alzado, servía como repisa para la colocación de otros restos escultóricos. Como sabemos, en el momento actual esa situación se reserva para la esfinge, pero lo cierto es que no conocemos por ahora ejemplos de esculturas adosadas a un lienzo de sillería, sino más bien de piezas que cumplen por sí mismas una función arquitectónica. Pensemos, por tanto, que esta escultura formaba parte integrante de un muro, de piedra o arcilla, que no tuvo necesariamente que ser el del monumento de remate piramidal, o por lo menos no hay prueba alguna que los reúna incontestablemente.

Tampoco las figuras que se recuperaron con la esfinge formaban, en principio, parte del monumento. Las más significativas son el toro y el torso de varón, que son figuras exentas (fig. 24). En el primer caso nos encontramos con una escultura que sigue las normas de un tipo muy original de bóvidos que se extienden desde Sagunto a la desembocadura del Segura, con una concentración importante en el Valle del Vinalopó (Chapa 2005 y 2005-2006). Se trata de toros en 
posición echada, que tienen en general orificios para insertar elementos postizos representando cuernos, orejas y lengua (Llobregat 1974). En su testuz a veces se dibuja un rectángulo de lados cóncavos, y en varios ejemplares se ha vaciado una zona inferior del cuerpo que serviría para albergar algún elemento no determinado o para ser encajada en un soporte.

El toro del Parque Infantil de Tráfico sigue la norma en lo referente al vaciado inferior y a los elementos accesorios, aunque también muestra considerables elementos originales. Los más importantes se refieren a las numerosas arrugas que cubren completamente su cuello y cabeza, formando diseños entrelazados que dejan espacio para incluir un ojo ovalado con pestañas indicadas. El segundo es la disposición de sus omóplatos, que se unen en la parte superior, lo que, junto a la mala conservación del ejemplar, hizo que se clasificara inicialmente como "pájaro". En tercer lugar, la posición del animal es anómala respecto al resto, ya que si aceptamos la propuesta expositiva, este toro estaría alzado sobre sus dos patas delanteras. Consideramos que no debe descartarse, en todo caso, la posibilidad de que estuviera echado, como todos los demás ejemplares de este grupo tipológico.

Finalmente, el torso varonil vaciado por la espalda tiene su paralelo geográfico más cercano en la propia Dama de Elche. En el ejemplar del Parque Infantil de Tráfico el orificio es proporcionalmente grande, dejando un reborde exterior de unos $5 \mathrm{~cm}$. El interior estaba ennegrecido, por lo que se le ha asignado una función de estatua-urna, sin que quede claro que su condición de busto sea original o fruto de la fractura inferior de la pieza. Tampoco resultan fáciles de entender los relieves que presenta su superficie, que han sido descritos como elementos de la vestimenta y el arma de un guerrero (Ramos Molina 2000: 46). La presencia de torsos con la espalda vaciada se extendió al menos hasta Baza (Granada), donde apareció una figura de las mismas características. Aunque desgraciadamente fuera de contexto, se considera obra de época ibérica tardía (Chapa y Olmos 1999).

En definitiva, debemos pensar que cerca de donde se colocó finalmente el alineamiento con los fragmentos tallados, existió un lugar en el que, entre otros restos no conservados o que apenas han dejado huella, hubo una estructura en la que se incluyó la esfinge con las figuras humanas, un toro con vaciado interno e importantes elementos postizos, y un torso de varón en el que parecen haberse depositado cenizas, ya sean de una cremación funeraria o de ofrendas quemadas. Probablemente estos dos últimos elementos tendrían sus propios soportes y actuarían como esculturas exentas relacionadas con el culto. Vincular el personaje masculino cuyo torso conservamos parcialmente y el alma del difunto que la esfinge transporta no puede pasar, hoy por hoy, de una idea incontrastable.

El paisaje de época ibérica en esta zona debió de constar de una serie de monumentos de carácter religioso y quizás funerario, aunque hasta el momento no se han hallado restos de enterramientos. Algo más al sur del Parque de Elche, dentro del casco antiguo, se recuperaron, siempre de forma casual, algunas de las mejores piezas escultóricas ibéricas ilicitanas (fig. 25). Una de ellas es una figura exenta de felino de excelente factura conservada en el Museo Municipal. La primera noticia la dio Ramos Folqués (1964: 673), quien indicó que conservaba líneas de pintura roja en la zona del cuello. Su hallazgo se produjo en terreno urbano, frente al Parque Municipal, al extraer tierras para cimentar un nuevo edificio. Aunque la pieza se encontraba a dos metros de profundidad, los informantes aseguraron que junto a ella había cerámica moderna, lo que llevó a Ramos Folqués a suponer que la escultura apareció en La Alcudia y fue trasladada a una colección particular en Elche, que finalmente se deshizo de ella. Más adelante, Ramos Folqués y Ramos Fernández (1976: 671) concretan que el subsuelo en el que apareció la leona correspondía a la casa llamada "Torre del Parque” (Ramos Folqués y Ramos Fernández 1976: 671). Otro fragmento de escultura se encontró en la cimentación de una vivienda en la Glorieta. Corresponde a la parte inferior de una pierna de guerrero revestida con una espinillera decorada, a la que se aferra una mano humana (Ramos Folqués 1966).

La presencia de restos de escultura en un entorno supuestamente alejado del núcleo urbano es un hecho relativamente frecuente en esta zona y los numerosos descubrimientos en los humedales de Monforte del Cid así parecen demostrarlo (Abad Casal et al. 1997). Sala Sellés (2007: 57) ha propuesto que la dedicación religiosa de estos espacios serviría para marcar un área de frontera entre la depresión meridional ilicitana y la cubeta del Vinalopó medio. Lo que parece claro es que la presencia de agua es un elemento importante para la concentración de estos monumentos, que tendrían una dedicación votiva y quizás funeraria, aunque no se hayan encontrado restos de verdaderas necrópolis.

Esto nos hace preguntarnos por las razones que condujeron a eliminar las esculturas de su primitivo emplazamiento y a fracturarlas significativamente. El monumento del Parque Infantil de Tráfico se encuentra, como indica Ramos Fernández (1987: 681) afectado por una villa 

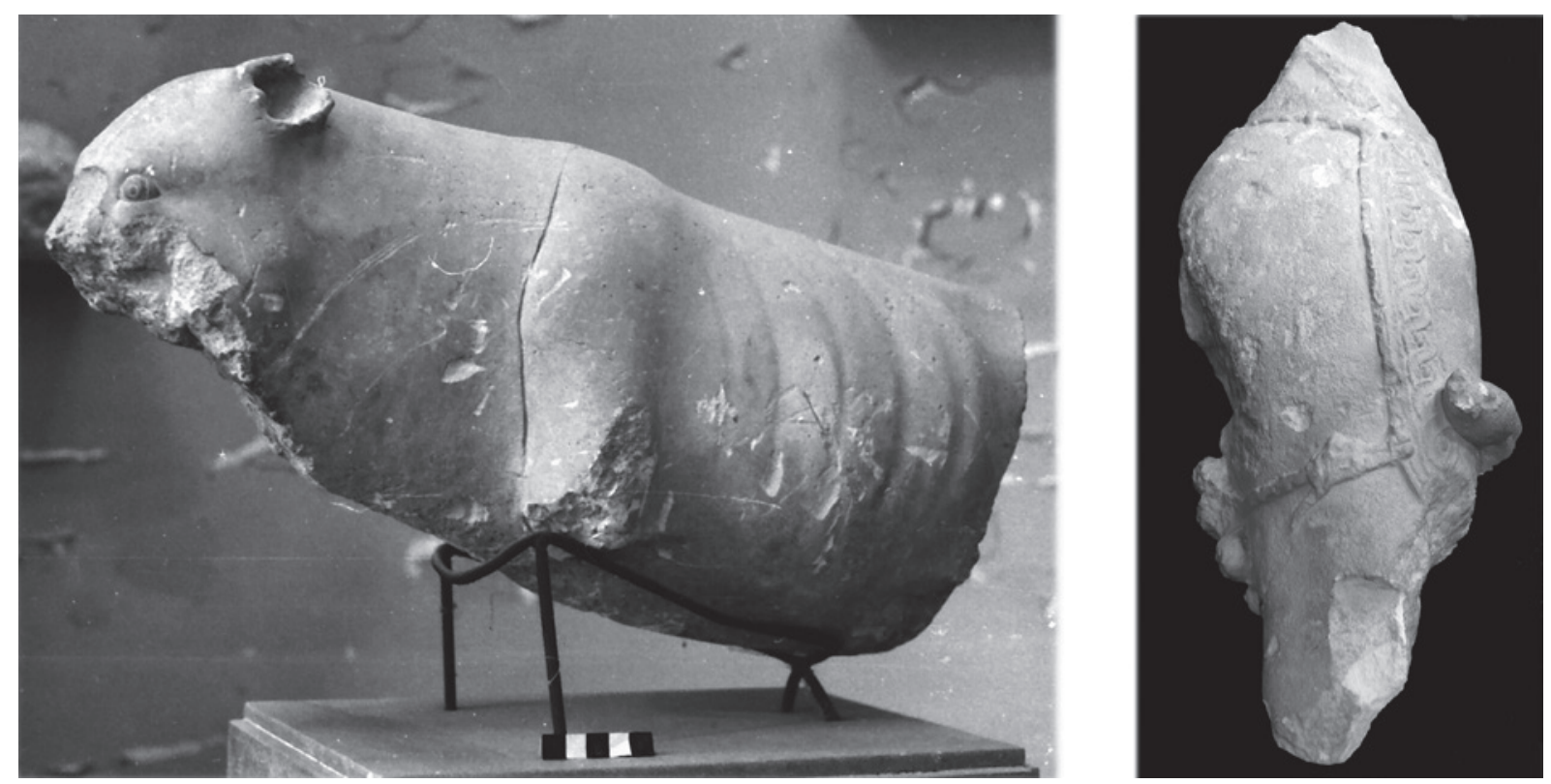

Figura 25. Esculturas de leona y mano agarrando una pierna con espinillera halladas al norte de la ciudad de Elche (Fotos T. Chapa).

romana encajada en el sistema de centuriación, pero los datos que se aportan en las distintas publicaciones del yacimiento no permiten relacionar la formalización del "témenos" con la reordenación romana del paisaje. Siguiendo las indicaciones de Ramos Fernández y Ramos Molina (1992: 21) el monumento fue privado de su decoración escultórica en la segunda mitad del s. V a.C. Las estatuas fueron troceadas, entibadas con fragmentos más pequeños de las mismas y colocadas delimitando un área de carácter religioso preexistente, que

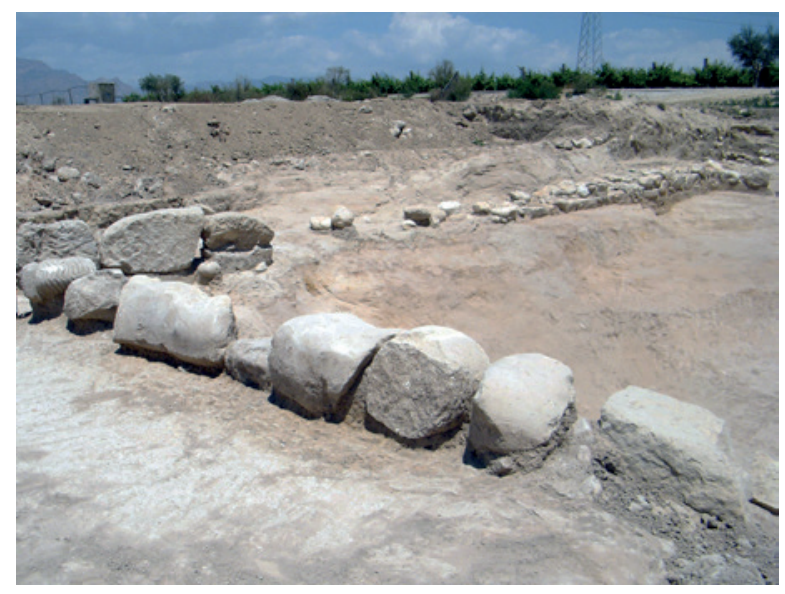

Figura 26. Alineamiento con restos escultóricos ibéricos encontrado en Monforte del Cid (Alicante) (Foto cortesía de Gabriel Segura. Arquealia). continuó funcionando al menos hasta fin de siglo (Ramos Fernández y Ramos Molina 1992: 25), sin que sepamos más sobre posibles perduraciones o indicios de abandono hasta época romana. Aunque sin un ensañamiento especial, puesto que los fragmentos escultóricos son grandes, el hecho de golpear las esculturas hasta romperlas y recolocar por separado sus trozos no es coherente con un respeto a su función ni a su representatividad religiosa. Debemos pensar que pierden su sentido original para pasar a un nuevo contexto, en el que su carácter sacro es más que dudoso.

Aunque en otro contexto cronológico más tardío, los hallazgos recientemente excavados en Monforte del $\mathrm{Cid}^{5}$, muestran un procedimiento de fragmentación y reutilización bastante próximo al del Parque Infantil de Tráfico de Elche (fig. 26). Las figuras incluyen varios toros y una pareja humana. Con ellas, embutidas en barro y piedras, se había formado un recinto cuadrangular que delimitaba una balsa. La fecha que proponen los excavadores para la realización de esta obra es el s. II o I a.C. Esta fecha permite relacionar el troceado de las esculturas de Monforte con las nuevas necesidades

5. Agradecemos a Gabriel Segura, responsable de la empresa Arquealia, el envío de la imagen que incluimos en este trabajo, ya que en este momento los hallazgos están todavía en proceso de estudio. Una noticia de los mismos puede revisarse en http://www.arquealia.es/uploads/noticias/Toros\%20Monforte.pdf (consultado el 29 de enero de 2012) 
y modos de explotación agrícola que sobrevienen en ápoca romana, y que comenzaron por la desecación de los campos afectados por los humedales del Vinalopó medio (Frías Castillejo 2010: 189). La extensión del área cultivada debió entrar en contradicción con los antiguos monumentos que ocupaban ciertas áreas y que no tenían cabida en la nueva estructura político-religiosa romana. El paisaje ibérico, que daba una singular importancia a la conmemoración religiosa mediante edificaciones y esculturas de carácter sacro, debió verse sustituido por una dedicación estrictamente económica que desplazó los antiguos usos indígenas y restringió sus expresiones escultóricas a los santuarios.

\section{BIBLIOGRAFÍA}

ABAD CASAL, L.; SALA SELLÉS, F. y ALBEROLA BELDA, E. M. S. (1997): "La necrópolis y el área sacra ibéricos de "Las Agualejas" (Monforte del Cid, Alicante)", Lucentum XIV-XVI: 7-18.

ALMAGRO-GORBEA, M. (2008): “Objetos de marfil y hueso”, en M. Almagro-Gorbea (dir), La necrópolis de Medellín II. Estudio de los hallazgos: 401512. Bibliotheca Archaeologica Hispana 26-2. Real Academia de la Historia, Madrid.

ALMAGRO-GORBEA, M. y TORRES, M. (2006): "Plástica sirio-fenicia en Occidente. La sirena de Villaricos y el origen de la plástica ibérica", Madrider Mitteilungen 47: 59-82.

- (2010): La escultura Fenicia en Hispania. Bibliotheca Praehistorica Hispana 32. Real Academia de la Historia, Madrid.

AUBET, Ma . E. (1976): “Algunos aspectos sobre iconografía púnica: Las representaciones aladas de Tanit”, Homenaje a García y Bellido, vol. 1, Revista de la Universidad Complutense XXV: 61-82. Madrid.

BARNETT, R.D. (1977): Illustrations of Old Testament History. British Museum Publications Limited. Londres.

BELÉN, M.; ANGLADA, R.; ESCACENA, J. L.; JIMÉNEZ, A.; LINEROS, R. y RODRÍGUEZ, I. (1997): Arqueología en Carmona (Sevilla). Excavaciones en la casa-palacio del Marqués de Saltillo. Consejería de Cultura de la Junta de Andalucía, Sevilla.

BENDALA GALÁN, M. (2005): "La Contestania Ibérica y el Mundo Púnico”, en L. Abad, F. Sala e I. Grau (eds.), La Contestania Ibérica, treinta años después: 37-52. Universidad de Alicante, Alicante.
BLANCO FREIJEIRO, A (1960): “Orientalia II”, Archivo Español de Arqueología 33: 1-43.

- (1961-1962): "El toro ibérico", Homenaje al Prof. C. de Mergelina: 163-195. Universidad de Murcia, Murcia.

- (1988): "Las esculturas de Porcuna. III. Animalia", Boletín de la Real Academia de la Historia CLXXXV: 206-234.

BLÁZQUEZ, J. M. (1956): "Pínax fenicio con esfinge y árbol sagrado", Zephyrus VII: 217-228.

BLECH, M. y RUANO RUIZ, E. (1993): “Dos esculturas ibéricas procedentes de Úbeda la Vieja (Jaén), Boletín de la Asociación Española de Amigos de la Arqueología 33: 27-44.

BONNET, C. (1991): “Tinnit, soeur cadette d'Astarté? A propos des cultes de Deir el-Qal'a près de Beyrouth", Die Welt des Orients 22: 73-84.

- (1996): Astarté. Dossier documentaire et perspectives historiques. (Contributi alla Storia della Religione Fenicio-Punica II). CNR, Roma.

BULlO, S. y ROSSIGNOLI, C. (1998): "Il santuario rurale di Bir Bou Rekba (Thinissut): uno studio iconografico ed alcune riconsiderazioni di carattere architettonico-planimetrico, en $\mathrm{M}$. Khanoussi, P. Ruggeri y C. Vismara (eds.), $L$ 'Africa Romana. Atti del XII convegno di studio vol. 1: 249-273. Editrice Democratica Sarda, Sassari.

CADOTTE, A. (2007): La romanisation des Dieux. L'interpretatio romana en Afrique du Nord sous le haut-Empire. Brill, Leiden-Boston.

CHAPA, T. (1980): "Las esfinges en la plástica ibérica", Trabajos de Prehistoria 37: 309-344.

- (1986): "Influences de la colonisation Phocéenne sur la Sculpture Ibèrique", La Parola del Passato. Rivista di Studi Antichi 104-107: 347-392.

- (2005): "Las primeras manifestaciones escultóricas ibéricas en el oriente peninsular", Archivo Español de Arqueología 78: 23-47.

- (2005-2006): "Iconografía y economía: un ejemplo aplicado a los orígenes de la escultura ibérica en el área del Bajo Segura (Alicante)", Homenaje a Jesús Altuna t. III. Munibe 5: 243-256.

CHAPA, T.; BELÉN, M.; MARTÍNEZ-NAVARRETE, M. I.; RODERO, A.; CEPRIÁN, B. y PEREIRA, J. (2009a): "Sculptor's signatures on Iberian stone statues from Ipolca-Obulco (Porcuna, Jaén, Spain)", Antiquity 83: 723-737.

CHAPA, T. y OLMOS, R. (1999): "El busto de varón de Baza (Granada). Una propuesta de lectura", en C. San Martín y M. Ramos (coords.), El guerrero 
de Baza: 33-40. Consejería de Cultura de la Junta de Andalucía, Granada.

CHAPA, T.; VALLEJO, I.; BELÉN, M.; MARTÍNEZNAVARRETE, M. I.; CEPRIÁN, B.; RODERO, A. y PEREIRA, J. (2009b): "El trabajo de los escultores ibéricos: un ejemplo de Porcuna (Jaén)", Trabajos de Prehistoria 66 (1): 161-173.

CHAPA, T.; VALLEJO, L. E. (e.p.): "El toro orientalizante de Porcuna", Complutum 2012.

CHAVES TRISTÁN, F. y DE LA BANDERA ROMERO, M. L. (1986): "Figürlich Verzierte Keramik aus dem Guadalquivir-Gebiet. Die Funde von Montemolín (bei Marchena, Prov. Sevilla)", Madrider Mitteilungen 27: 117-150.

COOK, B. F. (1976): Greek and roman art in the British Museum. British Museum Publications Limited, Londres.

DELCOR, M. (1983): “Les trônes d'Astarté”, Atti del I Congresso Internazionale di Studi Fenici e Punici, Roma 1979, vol III: 778-787. CNR, Roma.

FERNÁNDEZ GÓMEZ, F. (1989): "La fuente orientalizante del Gandul (Alcalá de Guadaira, Sevilla)", Archivo Español de Arqueología 62: 199-218.

FERRER, E. (2002): “Topografía sagrada del Extremo Occidente: santuarios, templos y lugares de culto de la Iberia púnica", en E. Ferrer (ed.), Ex Oriente Lux. Las religiones antiguas de la Península Ibérica: 185-217. Universidad de Sevilla, Sevilla.

FONTAN, E. y LE MEAUX, H. (eds.) (2007-2008): La Méditerranée des Phéniciens de Tyr à Carthage (Catalogue). Somogy Éditions d'Art, Institut du Monde Arabe, Paris.

FRÍAS CASTILLEJO, C. (2010): El poblamiento rural de Dianium, Lucentum, Ilici y la ciudad romana de la Vila Joiosa (siglos II a.C.-VII d.C.). Bases para su estudio. Publicaciones de la Universidad de Alicante, Alicante.

GAGNAISON, C., MONTENAT, Ch., BARRIER P. y ROUILLARD, P. (2007): "L'environnement du site ibérique de La Alcudia et les carrières antiques de la Dame d'Elche (Province d'Alicante, Espagne)", Archéosciences 31: 59-78.

GONZÁLEZ ALCALDE, J. (1997): “Simbología de la diosa Tanit en representaciones cerámicas ibéricas", Quaderns de Prehistòria i Arqueologia de Castelló 18. Espacios y lugares cultuales en el mundo ibérico: 329-343.

GONZÁLEZ NAVARRETE, J. (1987): Escultura Ibérica de Cerrillo Blanco, Porcuna, Jaén. Diputación Provincial de Jaén, Instituto de Cultura, Jaén.

GRIMAL, P. (1993): Diccionario de mitología griega y romana. Paidos, Barcelona, Buenos Aires, Méjico.
HERRMANN, G. (1989): "The Nimrud Ivories, 1: The Flame and Frond School", Iraq 51: 85-109.

- (2000): "Ivory carving of first millenium workshops, traditions and diffusion", en Ch. Uehlinger (ed), Images as media. Sources for the cultural history of the Near Eastern Mediterranean (Ist millenium BCE): 215-166. University Press, FriburgoVandenhoeck \& Ruprect, Göttingen.

HORNUNG, E. (1999): El Uno y los Múltiples. Concepciones egipcias de la divinidad. Ed. Trotta, Madrid.

HVIDBERG-HANSEN, F.O. (1979): La Déesse TNT. Un étude sur la religión canaanéo-punique. G.E.C. Gad's Forlag, Copenhague.

IZQUIERDO, I. (1999): "Parejas de esfinges y sirenas en las necrópolis ibéricas: una primera aproximación al tema", en R. de Balbín Behrmann y P. Bueno Ramírez (eds.), Congreso de Arqueología Peninsular. t. III. Primer Milenio y Metodología (Zamora, 1996): 413-424. Universidad de Alcalá de Henares, Fundación Rei Afonso Henriques, Madrid.

JIMÉNEZ ÁVILA, J. (2002): La toréutica orientalizante en la Península Ibérica. Real Academia de la Historia, Madrid.

KEEL, O. (2007): La iconografia del Antiguo Oriente y el Antiguo Testamento. Ed. Trotta, Madrid.

LE MEAUX, H. (2010): L'iconographie orientalisante de la Péninsule Ibérique. Questions de styles et d'échanges (VIIIe-Vie siècles av. J.-C.). Casa de Velázquez, Madrid.

LÓPEZ GRANDE, Ma J. (2003): Damas aladas del antiguo Egipto. Estudio iconográfico de una prerrogativa divina. Museu egipci de Barcelona, Fundació Arqueològica Clos, Barcelona.

LÓPEZ GRANDE, $M^{\mathrm{a}}$ J. y TRELLO ESPADA, J. (2004): "Pervivencias iconográficas egipcias en las imágenes de damas sagradas del ámbito fenicio-púnico", en A. González Blanco et al. (eds.), El Mundo Púnico. Religión, Antropología y cultura material-Actas del II Congreso Internacional del Mundo Púnico (Cartagena, 2000), [Estudios Orientales, 5-6, 2001-2002]: 337-352. Universidad de Murcia, Murcia.

LIPINSKI, E. (1995): Dieux et déesses de l'Univers phénicien et punique. Studia Phoenicia XIV. Uitgeverij Peeters \& Departement Oosterse Studies, Leuven

LLOBREGAT, E. A. (1974): "El toro ibérico de Villajoyosa (Alicante)", Zephyrus XXV: 335-342.

LÓPEZ PARDO, F. (2006): La torre de las almas. Un recorrido por los mitos y creencias del mundo 
fenicio y orientalizante a través del monumento de Pozo Moro. Gerión Anejos X. Publicaciones de la Universidad Complutense, Madrid.

MALUQUER DE MOTES, J. (1957): "De metalurgia tartésica. El Bronce Carriazo”, Zephyrus VIII: $157-$ 168.

MARÍN CEBALLOS, M. C. (1987): ¿Tanit en España?, Lucentum 6: 43-79.

- (1995): "La diosa leontocéfala de Cartago", Arqueólogos, historiadores y filólogos. Homenaje a Fernando Gascó, vol. II, Kolaios 4: 827-843. Sevilla.

MARÍN CEBALLOS, M. C., BELÉN DEAMOS, M. y JIMÉNEZ FLORES, A. M. (2010): "El proyecto de estudio de los materiales de la cueva de Es Culleram", Los púnicos de Iberia: proyectos, revisiones, sintesis. Mainake XXXII (1): 133-157.

MONEO, T. (2003): Religio Iberica. Santuarios, ritos $y$ divinidades (siglos VII-I A. C.), Madrid, Real Academia de la Historia.

MORATALLA, J. y VERDÚ, E. (2007): "Pebeteros con forma de cabeza femenina de la Contestania ibérica”, en M. C. Marín Ceballos y F. Horn (eds.), Imagen y culto en la Iberia Prerromana: Los pebeteros en forma de cabeza femenina. (Spal Monografías, IX): 339-366. Universidad de Sevilla, Sevilla.

NAVARRO GASCÓN, J. V. (2001): “Análisis de posibles restos de decoración en la «Esfinge del Salobral». Museo Arqueológico Nacional. Madrid", Boletín del Museo Arqueológico Nacional XIX,1: 50-51.

OLCINA DOMÉNECH, M. y RAMÓN SÁNCHEZ, J. (2009): "Esfinges de Agost", en M. Olcina Doménech y J. Ramón Sánchez (eds.), Huellas griegas en la Contestania Ibérica (Catálogo): 116-117. MARQ, Alicante.

OLMOS ROMERA, R. (2004): "La dama de Galera (Granada): la apropiación sacerdotal de un modelo divino", en J. Pereira, T. Chapa, A. Madrigal, A. Uriarte y V. Mayoral (eds.), La necrópolis ibérica de Galera (Granada). La colección del Museo Arqueológico Nacional: 213-237. Ministerio de Cultura, Subdirección General de Museos Estatales, Madrid.

- (2011): "En los umbrales de la muerte. Itinerarios del Más Allá en la imagen ibérica”, en J. Blánquez Pérez (ed.), ¿Hombres o dioses? Una nueva mirada a la escultura del mundo ibérico: 107-129. Museo Arqueológico Regional, Madrid.

OSBORNE, R. (1998): Archaic and Classic Greek Art. Oxford History of Art, Oxford University Press, Oxford.
PICARD, G. Ch. (1954) : Les religions de l'Afrique antique. Librairie Plon, Paris.

POVEDA, A. M. (1995): "IVNO CALESTIS en la colonia hispanorromana de ILICI", Espacio, Tiempo y Forma, Serie II, H ${ }^{a}$ Antigua, 8: 357-369.

- (1999): "Melqart y Astarté en el occidente mediterráneo: La evidencia de la Península Ibérica (siglos VIII-VI a.C.)", en B. Costa. y J. Fernández (eds.), De Oriente a Occidente: Los dioses fenicios en las colonias occidentales. XII Jornadas de Arqueología fenicio-púnica (Eivissa, 1997): 25-61. Govern Balear, Museu Arqueològic d'Eivissa i Formentera, Eivissa.

PRADOS MARTÍNEZ, F. (2002-2003): "Memoria del poder. Los monumentos funerarios ibéricos en el contexto de la arquitectura púnico-helenística", $\mathrm{Cu}$ PAUAM. Cuadernos de Prehistoria y Arqueología. Universidad Autónoma de Madrid 28-29: 203-226.

- (2008): Arquitectura Púnica. Los monumentos funerarios. Anejos de AEspA XLIV. Archivo Español de Arqueología. CSIC, Madrid.

- (2007): "A propósito del pilar-estela ibérico de Monforte del Cid (Alicante). Elementos para una discusión", Habis 38: 79-98.

QUILLARD, B. (1987): Bijoux Carthaginois II. Porteamulettes, sceaux-pendentifs, pendants, boucles, anneaux et bagues. Institut Supérieur d'Archéologie et d'Histoire de l'Art, Louvain-La-Neuve.

RAMÓN, J. (1982): Es Cuieram 1907-1982: 75 años de investigación. Delegación del Ministerio de Cultura de Ibiza y Formentera, Dirección General de la Juventud, Ibiza.

RAMOS FERNÁNDEZ, R. (1984-1985): "Matiz religioso de dos obras escultóricas del Parque de Elche", CuPAUAM. Cuadernos de Prehistoria y Arqueología. Universidad Autónoma de Madrid 13-14: 65-76.

- (1987): "Demarcación ibérica en el Parque de Elche", Actas del XVIII Congreso Nacional de Arqueología (Las Palmas y Santa Cruz de Tenerife, 1985): 681-677. Universidad de Zaragoza, Seminario de Arqueología, Zaragoza.

- (1988): "La escultura antropomorfa de Elche", Revista de Arqueología "Escultura Ibérica”: 94-105. Zugarto Ediciones, S.A., Madrid.

- (1989): "Vestigios de un posible monumento funerario ibérico en El Parque de Elche", Actas del XIX Congreso Nacional de Arqueología (Castellón de la Plana, 1987): 507-516. Universidad de Zaragoza, Zaragoza.

RAMOS FERNÁNDEZ, R. y RAMOS MOLINA, A. R. (1992): El Monumento y el Témenos Ibéricos del Parque de Elche. Ajuntament d'Elx, Elche. 
- (2004): "La escultura ibérica de La Alcudia", Iberia, Hispania, Spania. Una mirada desde Ilici: 133144. Caja de Ahorros del Mediterráneo, Alicante.

RAMOS FOLQUÉS, A. (1964): "Esculturas Ibéricas de Elche", Actas del Segundo Congreso Español de Estudios Clásicos (Madrid, 1961): 672673. Sociedad Española de Estudios Clásicos, Madrid.

- (1966): "Fragmento de escultura ibérica de Elche", Archivo de Prehistoria Levantina X: 149-153.

RAMOS FOLQUÉS, A. y RAMOS FERNÁNDEZ, R. (1976): "Excavaciones al este del Parque Infantil de Tráfico en Elche (Alicante)", Noticiario Arqueológico Hispánico 4 (Arqueología): 671-700.

RAMOS MOLINA, A. (2000): La escultura ibérica en el Bajo Vinalopó y Bajo Segura. Instituto Municipal de Cultura, Elche.

REMESAL RODRÍGUEZ, J. (1975): “Cerámicas orientalizantes andaluzas", Archivo Español de Arqueología 48: 3-21.

ROBINS, G. (2008): "Beauté idéale et emblèmes divins", en Chr. Ziegler (ed.), Reines d'Égypte d'Hétephérès à Cléopâtre: 118-131. Grimaldi Forum, Paris.

RUEDA GALÁN, C. (2007): "Los exvotos de bronce como expresión de la religiosidad ibérica del Alto Guadalquivir: la colección Gómez-Moreno", en L. Abad Casal y J. Soler Díaz (eds), Arte Ibérico en la España mediterránea. (Actas del Congreso, Alicante 24-27 de octubre 2005): 39-50. Instituto
Alicantino de Cultura Juan Gil Albert, Diputación Provincial de Alicante, Alicante.

SALA SELLÉS, F. (2004): "La influencia del mundo fenicio y púnico en las sociedades autóctonas del sureste peninsular", en B. Costa y J. H. Fernández (eds.), Colonialismo e interacción cultural: el impacto fenicio púnico en las sociedades autóctonas de occidente. XVIII Jornadas de Arqueología Fenicio-Púnica (Eivissa, 2003): 57-102. Govern de les Illes Balears, Museu Arqueològic d'Eivissa i Formentera, Eivissa.

- (2007): "Algunas reflexiones a propósito de la escultura ibérica de la Contestania y su entorno", en L. Abad Casal y J. Soler Díaz (eds), Arte Ibérico en la España mediterránea. (Actas del Congreso, Alicante 24-27 de octubre 2005): 51-82. Instituto Alicantino de Cultura Juan Gil Albert, Diputación Provincial de Alicante, Alicante.

SZNYCER, M. (1995): "La religion punique à Carthage", Carthage l'histoire, sa trace et son écho : 100-116. Paris, Les Musées de la Ville de Paris.

VERDÚ PARRA, E. (2009): "La llamada koré de Alicante", en M. Olcina Doménech y J. Ramón Sánchez (eds.), Huellas griegas en la Contestania Ibérica (Catálogo): 118. MARQ, Alicante.

XELLA, P. (1990): “«Divinités doubles» dans le monde phénico-punique", Mélanges Maurice Sznycer. Semitica XXXIX II: 167-175.

ZIEGLER, Chr. (2008): "Introduction", en Chr. Ziegler (ed.), Reines d'Égypte d'Hétephérès à Cléopâtre: 18-23. Grimaldi Forum, Paris. 